\title{
A phenomenology of new particle formation (NPF) at 13 European sites
}

\author{
Dimitrios Bousiotis ${ }^{1}$, Francis D. Pope ${ }^{1}$, David C. S. Beddows ${ }^{1}$, Manuel Dall'Osto ${ }^{2}$, Andreas Massling ${ }^{3}$, \\ Jakob Klenø Nøjgaard ${ }^{3,4}$, Claus Nordstrøm ${ }^{3}$, Jarkko V. Niemi ${ }^{5}$, Harri Portin ${ }^{5}$, Tuukka Petäjä ${ }^{6}$, Noemi Perez ${ }^{7}$, \\ Andrés Alastuey $^{7}$, Xavier Querol ${ }^{7}$, Giorgos Kouvarakis ${ }^{8}$, Nikos Mihalopoulos ${ }^{8}$, Stergios Vratolis ${ }^{9}$, \\ Konstantinos Eleftheriadis ${ }^{9}$, Alfred Wiedensohler ${ }^{10}$, Kay Weinhold ${ }^{10}$, Maik Merkel ${ }^{10}$, Thomas Tuch $^{10}$, and \\ Roy M. Harrison ${ }^{1,11}$ \\ ${ }^{1}$ Division of Environmental Health and Risk Management, School of Geography, Earth and Environmental Sciences, \\ University of Birmingham, Edgbaston, Birmingham, B15 2TT, United Kingdom \\ ${ }^{2}$ Institute of Marine Sciences, Passeig Marítim de la Barceloneta, 37-49, 08003, Barcelona, Spain \\ ${ }^{3}$ Department of Environmental Science, Aarhus University, 4000 Roskilde, Denmark \\ ${ }^{4}$ The National Research Centre for the Working Environment, Lers $\varnothing$ Parkalle 105, 2100 Copenhagen, Denmark \\ ${ }^{5}$ Helsinki Region Environmental Services Authority (HSY), 00066 HSY, Helsinki, Finland \\ ${ }^{6}$ Institute for Atmospheric and Earth System Research (INAR)/Physics, Faculty of Science, \\ University of Helsinki, Helsinki, Finland \\ ${ }^{7}$ Institute of Environmental Assessment and Water Research (IDAEA - CSIC), 08034, Barcelona, Spain \\ ${ }^{8}$ Environmental Chemical Processes Laboratory (ECPL), Department of Chemistry, University of Crete, \\ 70013, Heraklion, Greece \\ ${ }^{9}$ Environmental Radioactivity Laboratory, Institute of Nuclear and Radiological Science \& Technology, \\ Energy \& Safety, NCSR Demokritos, Athens, Greece \\ ${ }^{10}$ Leibniz Institute for Tropospheric Research (TROPOS), Permoserstr. 15, 04318 Leipzig, Germany \\ ${ }^{11}$ Department of Environmental Sciences/Center of Excellence in Environmental Studies, \\ King Abdulaziz University, P.O. Box 80203, Jeddah, 21589, Saudi Arabia
}

Correspondence: Roy M. Harrison (r.m.harrison@bham.ac.uk)

Received: 28 April 2020 - Discussion started: 4 September 2020

Revised: 27 May 2021 - Accepted: 18 June 2021ok - Published: 10 August 2021

\begin{abstract}
New particle formation (NPF) events occur almost everywhere in the world and can play an important role as a particle source. The frequency and characteristics of NPF events vary spatially, and this variability is yet to be fully understood. In the present study, long-term particle size distribution datasets (minimum of 3 years) from 13 sites of various land uses and climates from across Europe were studied, and NPF events, deriving from secondary formation and not traffic-related nucleation, were extracted and analysed. The frequency of NPF events was consistently found to be higher at rural background sites, while the growth and formation rates of newly formed particles were higher at roadsides (though in many cases differences between the sites were small), underlining the importance of the abundance
\end{abstract}

of condensable compounds of anthropogenic origin found there. The growth rate was higher in summer at all rural background sites studied. The urban background sites presented the highest uncertainty due to greater variability compared to the other two types of site. The origin of incoming air masses and the specific conditions associated with them greatly affect the characteristics of NPF events. In general, cleaner air masses present higher probability for NPF events, while the more polluted ones show higher growth rates. However, different patterns of NPF events were found, even at sites in close proximity $(<200 \mathrm{~km})$, due to the different local conditions at each site. Region-wide events were also studied and were found to be associated with the same conditions as local events, although some variability was found which 
was associated with the different seasonality of the events at two neighbouring sites. NPF events were responsible for an increase in the number concentration of ultrafine particles of more than $400 \%$ at rural background sites on the day of their occurrence. The degree of enhancement was less at urban sites due to the increased contribution of other sources within the urban environment. It is evident that, while some variables (such as solar radiation intensity, relative humidity, or the concentrations of specific pollutants) appear to have a similar influence on NPF events across all sites, it is impossible to predict the characteristics of NPF events at a site using just these variables, due to the crucial role of local conditions.

\section{Introduction}

Ultrafine particles (particles with diameter smaller than $100 \mathrm{~nm}$ ), while not yet regulated, are believed to have adverse effects upon air quality and public health (Atkinson et al., 2010; Politis et al., 2008; Tobías et al., 2018), as well as having a direct or indirect effect on atmospheric properties (Makkonen et al., 2012; Seinfeld and Pandis, 2012). The source of ultrafine particles can either be from primary emissions (Harrison et al., 2000; Masiol et al., 2017), including delayed primary emissions (Hietikko et al., 2018; Olin et al., 2020; Rönkkö et al., 2017), or from secondary formation from gaseous precursors (Brean et al., 2019; Chu et al., 2019; Kerminen et al., 2018; Kulmala et al., 2004a; Yao et al., 2018), which is considered an important source of cloud condensation nuclei $(\mathrm{CCN})$ in the atmosphere (Dameto de España et al., 2017; Kalivitis et al., 2015; Spracklen et al., 2008). For the latter, while the process of formation of initial clusters that subsequently lead to particle formation has been extensively studied (Dal Maso et al., 2002; Kulmala et al., 2014; Riipinen et al., 2007; Weber et al., 1998), there is no consistent explanation of the factors which determine the occurrence and development of new particle formation (NPF) events in the atmosphere. Additionally, events that resemble NPF, with the initial particles deriving from primary emissions, especially close to traffic sources (Rönkkö et al., 2017), have also been reported, but these are out of the scope of the present study.

A large number of studies both in laboratories and in realworld conditions have been conducted to either describe or explain the mechanisms that drive NPF events. The role of meteorological conditions, such as solar radiation intensity (Kumar et al., 2014; Shi et al., 2001; Stanier et al., 2004) and relative humidity (Li et al., 2019; Park et al., 2015), is well documented, while great diversity was found for the effect of other meteorological factors such as the wind speed (Charron et al., 2008; Németh and Salma, 2014; Rimnácová et al., 2011) or temperature (Jeong et al., 2010; Napari et al., 2002). There are also influences of atmospheric composition, with the positive role of low condensation sink and concen- trations of pollutants such as $\mathrm{NO}_{x}$ in NPF event occurrence being widely agreed upon (Alam et al., 2003; Cheung et al., 2013; Kerminen et al., 2004; Wang et al., 2014; Wehner et al., 2007). Contrary to that, while the indirect role of $\mathrm{SO}_{2}$ is well established in the nucleation process, via the formation of new clusters of $\mathrm{H}_{2} \mathrm{SO}_{4}$ molecules (Boy et al., 2005; Iida et al., 2008; Kulmala et al., 2005; Sipila et al., 2010; Xiao et al., 2015), uncertainty exists in the role that different concentrations of $\mathrm{SO}_{2}$ play in the occurrence of NPF events in realworld atmospheric conditions (Alam et al., 2003; Dall'Osto et al., 2018; Wonaschütz et al., 2015; Woo et al., 2001). Ammonia is known to enhance the formation of initial clusters (Korhonen et al., 1999; Ortega et al., 2008; Schobesberger et al., 2015), and volatile organic compounds are regarded as the main drivers of the growth of the newly formed particles (Kulmala et al., 2013; Riccobono et al., 2014; Tröstl et al., 2016). NPF events in different locations do not appear to follow consistent trends with the concentrations of these compounds and meteorological parameters (McFiggans et al., 2019; Minguillón et al., 2015; Riipinen et al., 2007), though links between NPF events and sulfuric acid vapour concentrations (Petäjä et al., 2009; Weber et al., 1995) and organics (Bianchi et al., 2019; Ehn et al., 2014) have been reported.

It is evident that NPF events and their development are complex, and local conditions play an important role in their variability. Many studies have attempted to explain this variability by analysing multiple datasets from wider areas. Studies in the UK (Bousiotis et al., 2019; Hama et al., 2017), Spain (Brines et al., 2014; Carnerero et al., 2018; Dall'Osto et al., 2013; Minguillón et al., 2015), Hungary (Németh and Salma, 2014; Salma et al., 2014, 2016), Greece (Kalkavouras et al., 2017; Siakavaras et al., 2016), Germany (Costabile et al., 2009; Ma and Birmili, 2015; Sun et al., 2019), and China (Peng et al., 2017; Shen et al., 2018; Wang et al., 2017) have attempted to explain the differences found in NPF event conditions and variability between different sites in close proximity, while larger scale studies using descriptive (Brines et al., 2015; Hofman et al., 2016; Jaatinen et al., 2009; Kulmala et al., 2005) or statistical methods (Dall'Osto et al., 2018; Rivas et al., 2020) have provided insights into the effect of the variability of parameters that are considered to play an important role in the occurrence and development of NPF events on a broader scale.

The present study, combining 13 long-term datasets (minimum of 3 years) from different countries across Europe, and combined with the results from a previous study in the UK, attempts to elucidate the effect of the local conditions on NPF event characteristics (frequency of NPF events, formation rate, and growth rate), both for sites in close proximity $(<200 \mathrm{~km})$ and by intercomparison of sites on a continental scale in order to find general trends of the variables that affect the characteristics and development of NPF events on a larger scale. Finally, the effect of NPF events upon the ultrafine particle number concentrations was calculated, provid- 


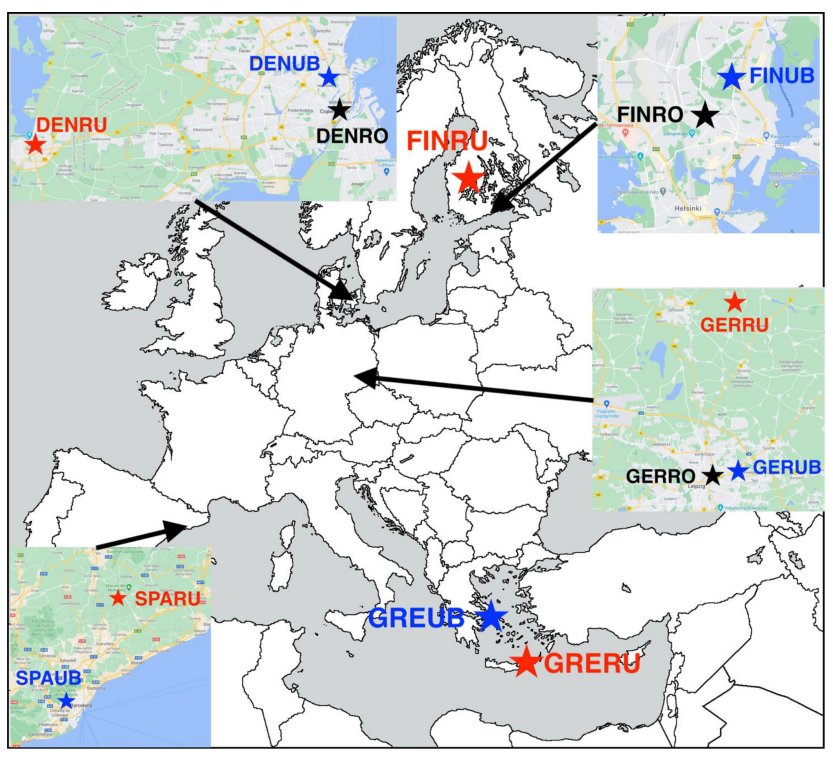

Figure 1. Map of the areas of study (map by (C) Google Maps).

ing insight into the potential of NPF events to influence the local air quality conditions in all areas studied.

\section{Data and methods}

\subsection{Site description and data availability}

In the present study, particle number size distribution data from 13 sites in Europe (Fig. 1) are analysed in the size range $3 \mathrm{~nm}<D_{\mathrm{p}}<1000 \mathrm{~nm}$. A detailed list of the site locations and the data available for each is found in Table 1 (seasonal data availability is found in Table S1 in the Supplement). For site naming, the first three letters refer to the country $(\mathrm{DEN}=$ Denmark, GER $=$ Germany, FIN $=$ Finland, $\mathrm{SPA}=$ Spain, GRE $=$ Greece), while the next two refer to the type of site $(\mathrm{RU}=$ rural background, $\mathrm{UB}=$ urban background, $\mathrm{RO}=$ roadside). Average meteorological conditions and concentrations of chemical compounds for all sites are found in Tables S2 and S3 respectively; their seasonal variation is found in Table $\mathrm{S} 4$.

\subsection{Methods}

\subsubsection{NPF event selection}

The identification of NPF events was conducted manually using the criteria set by Dal Maso et al. (2005). According to these, a NPF event is considered to occur when the following conditions are met:

- A distinctly new mode of particles appears in the nucleation range.

- This new mode prevails for some hours.
- The new mode shows signs of growth.

The NPF events extracted using this method are then classified into classes I or II depending on the level of confidence. Class I (high confidence) is further classified as Ia and $\mathrm{Ib}$, with Class Ia containing the events that both present a clear formation of a new mode and a distinct growth of this mode, while Ib includes those with a less distinct formation and development. In the present study, only the events classified as Ia were used as they are considered more suitable for study. As the growth criterion is not fully defined, in the present study, a minimum growth rate of $1 \mathrm{~nm} \mathrm{~h}^{-1}$ is required for NPF events to be considered. The events found using this method should not be confused with the formation and growth of particles deriving from primary emissions next to pollution sources, such as traffic. While to an extent the particle formation found can be biased by primary emissions (especially at roadside sites), great effort was made using additional data, such as atmospheric composition data, to not include any incidents of traffic-related nucleation.

\subsubsection{Calculation of condensation sink, growth rate, formation rate, nucleation strength factor (NSF), and NPF event probability}

The calculation of the condensation sink was made using the method proposed by Kulmala et al. (2001). The condensation sink (CS) is calculated as

$\mathrm{CS}=4 \pi D_{\text {vap }} \sum \beta_{\mathrm{M}} r N$,

where $r$ and $N$ are the radius and the number concentration of the particles and $D_{\text {vap }}$ is the diffusion coefficient, calculated for $T=293 K$ and $P=1013.25 \mathrm{mbar}$, according to Poling et al. (2001):

$$
D_{\text {vap }}=0.00143 \cdot T^{1.75} \frac{\sqrt{M_{\text {air }}^{-1}+M_{\text {vap }}^{-1}}}{P\left(D_{x, \text { air }}^{\frac{1}{3}}+D_{x, \text { vap }}^{\frac{1}{3}}\right)^{2}},
$$

where $M$ and $D_{x}$ are the molar mass and diffusion volume for air and $\mathrm{H}_{2} \mathrm{SO}_{4} . \beta_{M}$ is the Fuchs correction factor calculated from Fuchs and Sutugin (1971):

$\beta_{M}=\frac{1+K n}{1+\left(\frac{4}{3 a}+0.377\right) K n}+\frac{4}{3 a} K n^{2}$,

where $K n$ is the Knudsen number, defined as $K n=2 \lambda_{\mathrm{m}} / d_{\mathrm{p}}$, with $\lambda_{\mathrm{m}}$ being the mean free path of the gas.

The growth rate of the newly formed particles is calculated according to Kulmala et al. (2012) as

$\mathrm{GR}=\frac{D_{\mathrm{P}_{2}}-D_{\mathrm{P}_{1}}}{t_{2}-t_{1}}$

for the size range of the minimum available particle diameter up to $30 \mathrm{~nm}$. For the calculation of the growth rate, the time 
Table 1. Location and data availability (seasonal data availability can be found in Table S4) of the sites in the present study. In the studies referenced, an extended description of the sites can be found (SMPS - scanning mobility particle sizer; DMPS - differential mobility particle sizer; TDMPS - twin differential mobility particle sizer; CPC - condensation particle counter).

\begin{tabular}{|c|c|c|c|c|c|}
\hline Site & Location & Available data & $\begin{array}{l}\text { Meteorological } \\
\text { data location }\end{array}$ & $\begin{array}{l}\text { Data } \\
\text { availability }\end{array}$ & Reference \\
\hline DENRU & $\begin{array}{l}\text { Lille Valby, } 25 \mathrm{~km} \mathrm{~W} \text { of Copenhagen, } \\
\left(55^{\circ} 41^{\prime} 41^{\prime \prime} \mathrm{N} ; 12^{\circ} 7^{\prime} 7^{\prime \prime} \mathrm{E}\right) \\
(2008-\mathrm{Jun} 2010) \\
\text { Ris } \varnothing, 7 \mathrm{~km} \text { north of Lille Valby, } \\
\left(55^{\circ} 38^{\prime} 40^{\prime \prime} \mathrm{N} ; 12^{\circ} 5^{\prime} 19^{\prime \prime} \mathrm{E}\right) \\
\text { (July } 2010-2017)\end{array}$ & $\begin{array}{l}\text { DMPS and } \mathrm{CPC}(5.8-700 \mathrm{~nm}, \\
65.4 \% \text { availability), } \mathrm{NO}, \mathrm{NO}_{x} \text {, } \\
\mathrm{SO}_{2}, \mathrm{O}_{3} \text {, minerals, } \mathrm{OC}, \mathrm{EC}, \mathrm{NO}_{3}^{-} \text {, } \\
\mathrm{SO}_{4}^{2-}, \mathrm{NH}_{4}^{+}\end{array}$ & $\begin{array}{l}\emptyset \text { rsted - Insti- } \\
\text { tute station }\end{array}$ & 2008-2017 & $\begin{array}{l}\text { Ketzel et al. } \\
(2004)\end{array}$ \\
\hline DENRO & $\begin{array}{l}\text { H.C. Andersens Boulevard, Copen- } \\
\text { hagen, Denmark }\left(55^{\circ} 40^{\prime} 28^{\prime \prime} \mathrm{N} \text {; }\right. \\
\left.12^{\circ} 34^{\prime} 16^{\prime \prime} \mathrm{E}\right)\end{array}$ & $\begin{array}{l}\text { DMPS and CPC }(5.8-700 \mathrm{~nm}, \\
65.0 \% \text { availability), } \mathrm{NO}, \mathrm{NO}_{x}, \\
\mathrm{SO}_{2}, \mathrm{O}_{3}, \text { minerals, } \mathrm{OC}, \mathrm{EC}, \mathrm{NO}_{3}^{-} \text {, } \\
\mathrm{SO}_{4}^{2-}, \mathrm{NH}_{4}^{+}\end{array}$ & $\begin{array}{l}\text { Ørsted - Insti- } \\
\text { tute station }\end{array}$ & $2008-2017$ & $\begin{array}{l}\text { Wang et al. } \\
(2010)\end{array}$ \\
\hline GERUB & $\begin{array}{l}\text { TROPOS, } 3 \mathrm{~km} \mathrm{NE} \text { of the city centre } \\
\text { of Leipzig, Germany }\left(51^{\circ} 21^{\prime} 9.1^{\prime \prime} \mathrm{N} \text {; }\right. \\
\left.12^{\circ} 26^{\prime} 5.1^{\prime \prime} \mathrm{E}\right)\end{array}$ & $\begin{array}{l}\text { TDMPS with CPC }(3-800 \mathrm{~nm} \text {, } \\
88.0 \% \text { availability) }\end{array}$ & On-site & 2008-2011 & $\begin{array}{l}\text { Birmili et al. } \\
(2016)\end{array}$ \\
\hline GERRO & $\begin{array}{l}\text { Eisenbahnstraße, Leipzig, Germany } \\
\left(51^{\circ} 20^{\prime} 43.80^{\prime \prime} \mathrm{N} ; 12^{\circ} 24^{\prime} 28.35^{\prime \prime} \mathrm{E}\right)\end{array}$ & $\begin{array}{l}\text { TDMPS with CPC }(4-800 \mathrm{~nm} \text {, } \\
64.4 \% \text { availability) }\end{array}$ & $\begin{array}{l}\text { TROPOS } \\
\text { station }\end{array}$ & 2008-2011 & $\begin{array}{l}\text { Birmili et al. } \\
(2016)\end{array}$ \\
\hline FINRU & $\begin{array}{l}\text { Hyytiälä, } 250 \mathrm{~km} \mathrm{~N} \text { of Helsinki, } \\
\text { Finland }\left(61^{\circ} 50^{\prime} 50.70^{\prime \prime} \mathrm{N}\right. \\
\left.24^{\circ} 17^{\prime} 41.20^{\prime \prime} \mathrm{E}\right)\end{array}$ & $\begin{array}{l}\text { TDMPS with } \mathrm{CPC}(3-1000 \mathrm{~nm} \text {, } \\
98.7 \% \text { availability), } \mathrm{NO}, \mathrm{NO}_{x}, \\
\mathrm{SO}_{2}, \mathrm{O}_{3}, \mathrm{CO}, \mathrm{CH}_{4}, \mathrm{VOCs}, \mathrm{H}_{2} \mathrm{SO}_{4}\end{array}$ & On-site & $\begin{array}{l}2008-2011 \& \\
2015-2018\end{array}$ & $\begin{array}{l}\text { Aalto et al. } \\
(2001)\end{array}$ \\
\hline SPAUB & $\begin{array}{l}\text { Palau Reial, Barcelona, } \\
\text { Spain }\left(41^{\circ} 23^{\prime} 14^{\prime \prime} \mathrm{N} ; 2^{\circ} 6^{\prime} 56^{\prime \prime} \mathrm{E}\right)\end{array}$ & $\begin{array}{l}\text { SMPS }(10.9-478 \mathrm{~nm}, 64.2 \% \text { avail- } \\
\text { ability), } \mathrm{NO}, \mathrm{NO}_{2}, \mathrm{SO}_{2}, \mathrm{O}_{3}, \mathrm{CO} \text {, } \\
\mathrm{BC}, \mathrm{OM}, \mathrm{SO}_{4}^{2-}, \mathrm{PM}_{2.5}, \mathrm{PM}_{10}\end{array}$ & On-site & 2012-2015 & $\begin{array}{l}\text { Dall'Osto et al. } \\
\text { (2012) }\end{array}$ \\
\hline GRERU & $\begin{array}{l}\text { Finokalia, } 70 \mathrm{~km} \mathrm{E} \text { of Heraklion, } \\
\text { Greece }\left(35^{\circ} 20^{\prime} 16.8^{\prime \prime} \mathrm{N}\right. \\
\left.25^{\circ} 40^{\prime} 8.4^{\prime \prime} \mathrm{E}\right)\end{array}$ & $\begin{array}{l}\text { SMPS }(8.77-849 \mathrm{~nm}, 92.4 \% \text { avail- } \\
\text { ability), } \mathrm{NO}, \mathrm{NO}_{2}, \mathrm{O}_{3}, \mathrm{OC}, \mathrm{EC}\end{array}$ & On-site & 2012-2018 & $\begin{array}{l}\text { Kalkavouras et } \\
\text { al. (2017) }\end{array}$ \\
\hline GREUB & $\begin{array}{l}\text { "Demokritos", } 12 \mathrm{~km} \mathrm{NE} \text { of } \\
\text { the city centre, Athens, Greece } \\
\left(37^{\circ} 59^{\prime} 41.96^{\prime \prime} \mathrm{N} ; 23^{\circ} 48^{\prime} 57.56^{\prime \prime} \mathrm{E}\right)\end{array}$ & $\begin{array}{l}\text { SMPS }(10-550 \mathrm{~nm}, 77.2 \% \text { avail- } \\
\text { ability) }\end{array}$ & On-site & 2015-2018 & $\begin{array}{l}\text { Stafoggia et al. } \\
(2017)\end{array}$ \\
\hline
\end{tabular}


considered was from the start of the event until (a) growth stopped, (b) GMD (geometric mean diameter) reached the upper limit set, or (c) the day ended. Due to the differences in the smallest particle size available between the sites, a discrepancy would exist for the growth rate values presented (sites with lower size cut would present lower values of growth rate, as the growth rate tends to increase with particle size in this range; Deng et al., 2020). As a result, a direct comparison of the growth rate values found among sites with significant differences at the smallest particle size available was avoided.

The formation rate $J$ was calculated using the method proposed by Kulmala et al. (2012) in which

$J_{d_{\mathrm{p}}}=\frac{\mathrm{d} N_{d_{\mathrm{p}}}}{\mathrm{d} t}+\operatorname{CoagS}_{d_{\mathrm{p}}} \times N_{d_{\mathrm{p}}}+\frac{\mathrm{GR}}{\Delta d_{\mathrm{p}}} \times N_{d_{\mathrm{p}}}+S_{\text {losses }}$,

where CoagS $S_{d_{\mathrm{p}}}$ is the coagulation rate of particles of diameter $d_{\mathrm{p}}$, calculated by

$$
\begin{aligned}
\operatorname{CoagS}_{d_{\mathrm{p}}} & =\int K\left(d_{\mathrm{p}}, d_{\mathrm{p}}^{\prime}\right) n\left(d_{\mathrm{p}}^{\prime}\right) \mathrm{d} d_{\mathrm{p}}^{\prime} \\
& \cong \sum_{d_{\mathrm{p}}^{\prime}=d_{\mathrm{p}}}^{d_{\mathrm{p}}^{\prime}=\max } K\left(d_{\mathrm{p}}, d_{\mathrm{p}}^{\prime}\right) N_{d_{\mathrm{p}}},
\end{aligned}
$$

as proposed by Kerminen et al. (2001). $K\left(d_{\mathrm{p}}, d_{\mathrm{p}}^{\prime}\right)$ is the coagulation coefficient of particle sizes $d_{\mathrm{p}}$ and $d_{\mathrm{p}}^{\prime}$. $S_{\text {losses }}$ accounts for the additional loss terms (i.e. chamber walls), not considered here. Initial particle formation starts at about $1.5 \pm 0.4 \mathrm{~nm}$ (Kulmala et al., 2012). The formation rate calculated here refers to particles in the atmosphere that reached the diameter of $10 \mathrm{~nm}$ during NPF events for uniformity reasons. This means that these particles were formed earlier during the day of the events, survived, and grew to this size later in the day. Furthermore, due to the effect of the morning rush which biased the results at roadsides, the averages are calculated for the time window between 09:00 and 15:00 LT $( \pm 3 \mathrm{~h}$ from noon, when $J_{10}$ peaked in the majority of the events). This was done for all the sites in this study for consistency.

As mentioned in the methodology, for NPF event selection (Sect. 2.2.1), days with particle formation resulting directly from traffic emissions were excluded. For those identified as NPF event days though, mainly for the roadside sites, formation associated with traffic emissions still occurs. It is impossible with the data available for this study to remove the traffic-related particle formation in the calculations included in this study, by effectively separating it from secondary particle formation or calculating it. Using average conditions for comparison would lead to negative formation rate values in most cases, since in order for an NPF event to occur, traffic-related particles are usually reduced to a greater extent compared to the formation from NPF, leading to lower particle concentrations on event days as found from a previous study in Marylebone Road, London (Bousiotis et al., 2019).
This may result in an overestimation of the formation rates at roadside sites presented in this study. The choice of a time window for which we would have the maximum effect of secondary particle formation and the minimum possible effect from traffic-related particle formation attempts to reduce this discrepancy as much as possible.

The nucleation strength factor (NSF) proposed by Németh and Salma (2014) is a measure of the effect of NPF events on ultrafine particle concentration. It can either refer to the effect of NPF events on the day of their occurrence, calculated by

$\mathrm{NSF}_{\text {NUC }}=\frac{\left(\frac{N_{\text {smallest size available-100 } \mathrm{nm}}}{N_{100 \mathrm{~nm} \text {-largest size available }}}\right)_{\text {nucleation days }}}{\left(\frac{N_{\text {smallest size available-100 } \mathrm{nm}}}{N_{100 \mathrm{~nm}-\text { largest size available }}}\right)_{\text {non-nucleation days }}}$,

or their overall contribution on the ultrafine particle concentrations at a site, calculated by

$$
\mathrm{NSF}_{\text {GEN }}=\frac{\left(\frac{N_{\text {smallest size available-100 } \mathrm{nm}}}{N_{100 \mathrm{~nm} \text {-largest size available }}}\right)_{\text {all days }}}{\left(\frac{N_{\text {smallest size available-100 } \mathrm{nm}}}{N_{100 \mathrm{~nm}-\text { largest size available }}}\right)_{\text {non-nucleation days }}} .
$$

The NPF event probability is a simple metric of the probability of NPF events calculated by the number of NPF event days divided by the number of days with available data for the given group (temporal, wind direction, etc.). Finally, it should be mentioned that all the results presented are normalized according to the seasonal data availability for each site, based upon the following expression:

$\mathrm{NPF}_{\text {probability }}=\frac{N_{\mathrm{NPF} \text { event days for group of days } X}}{N_{\text {days with available data for group of days } X}}$.

\section{Results}

The seasonal NPF probability for all sites is found in Table S5. The annual number of NPF events, growth rate, and formation rate for all the sites is found in Table S6, for which no clear interannual trend is found for any of the sites in this study. This may be due to the relatively short period of time studied for such variations to be observed.

\subsection{Frequency and seasonality of NPF events}

In Denmark, NPF events occurred at all three sites, with a similar frequency for the urban sites $(5.4 \%$ for DENRO and $5.8 \%$ for DENUB) and a higher frequency for the rural DENRU site $(7.9 \%)$. The seasonal variation favoured summer at DENRU and DENRO, while at DENUB, a similar frequency for spring and summer was found (Fig. 2). The within-week variation of the events favours weekends compared to weekdays going from the rural background site to the roadside site (Fig. 3). Interesting is the increased frequency of NPF events found in all Danish sites on Thursday among the weekdays. This trend though does not have a plausible explanation and is probably coincidental. 


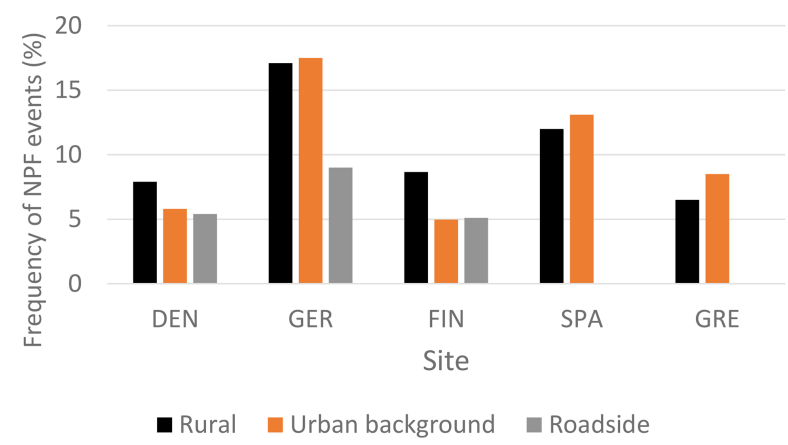

(a)

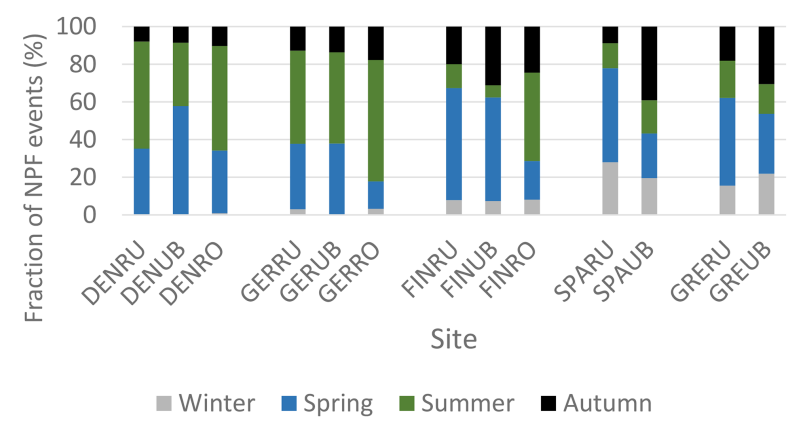

(b)

Figure 2. Frequency (a) and seasonal variation (b) of new particle formation events (winter - DJF; spring - MAM; summer - JJA; autumn - SON).

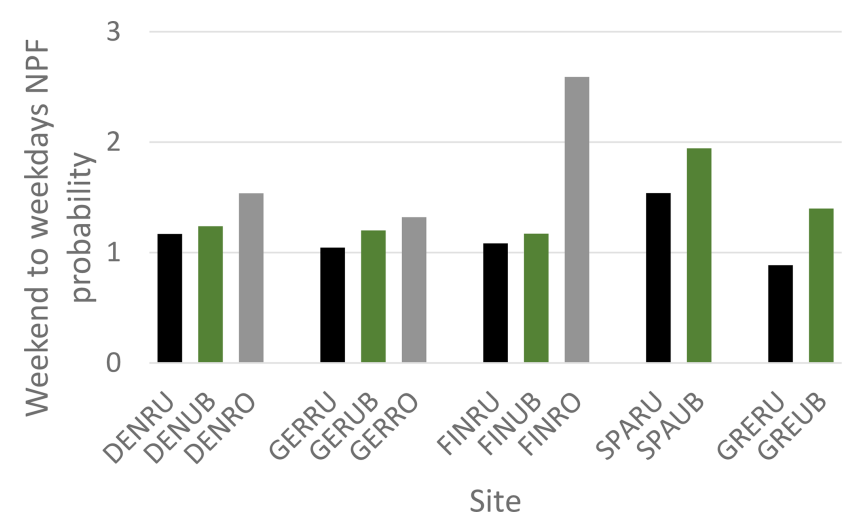

Figure 3. Ratio of new particle formation event probability between weekends and weekdays. The greater the ratio, the more probable it is for an event to take place during weekends compared to weekdays.

A higher frequency of events for all types of environments is found for the German sites compared to all other countries in this study. The background sites had NPF events for more than $17 \%$ of the days, while the roadside had a lower frequency of about $9 \%$, with a seasonal variability favouring summer at all sites. It should be noted though that, due to the lack of spring and summer data for the first 2 years at the German roadside site, the frequency of events is probably a lot higher, and the seasonal variation should further favour these seasons. No substantial within-week variation was found for any of the sites in this country, a feature that is expected mainly at background sites. For GERRO, this may be due to not being as polluted as other sites of the same type, having an average condensation sink comparable to that of urban background sites in this study.

NPF events at the sites in Finland presented the most diverse seasonal variation, peaking at the background sites in spring and at the roadside site in summer (while the spring data availability is somewhat reduced for the Finnish roadside site, the general trend remains the same if all seasons had the same data availability). The frequency of NPF events at FINRU was higher (8.66\%) compared to the urban sites ( $4.97 \%$ at FINUB and $5.20 \%$ at FINRO). Strong withinweek variation favouring weekends is found for the roadside site, while no clear variation was found for the background sites. This may be due to either the higher condensation sink during weekdays that suppresses the events or the dominant impact of the traffic emissions, which could make the detection of NPF events harder.

For Spain, data were available for an urban and a rural background site in the greater area of Barcelona. NPF events were rather frequent, occurring on about $12 \%$ of the days at the rural background site and $13.1 \%$ at the urban site. Though the sites are in close proximity (about $50 \mathrm{~km}$ ), the seasonality of NPF events was different between them, peaking in spring at SPARU and autumn at SPAUB. The frequency of NPF events in winter was relatively high compared to the sites in central and northern Europe and higher than summer for both sites. For both sites a higher NPF probability was found on weekends compared to weekdays, though this trend is stronger at SPAUB.

Finally, for Greece, data are available for two background sites, though not in close proximity (the distance between the sites is about $350 \mathrm{~km}$ ). While in Greece meteorological conditions are favourable in general for NPF events, with high solar radiation and low relative humidity, their frequency was only $8.5 \%$ for the urban background site in Athens and $6.5 \%$ for the rural background site in Finokalia, similar to the frequency of Class I events reported in the study by Kalivitis et al. (2019). Most NPF events occurred in spring at both sites, peaking in April. It is interesting that the sites in southern Europe (in Spain and Greece) have a considerable number of NPF events during winter, which might be due to the specific meteorological conditions found in this area, where winter is a lot warmer than at the sites in northern and central Europe, and insolation is higher.

\subsection{Formation and growth rates}

For the Danish sites, the growth rate was found to be higher at the roadside site at $4.45 \pm 1.87 \mathrm{~nm} \mathrm{~h}^{-1}$, and it was similar for the other two sites $(3.19 \pm 1.43$ for DENRU and $3.19 \pm 1.45 \mathrm{~nm} \mathrm{~h}^{-1}$ for DENUB) (Fig. 4), though the peak was found in different seasons (Fig. 5), coinciding with that 


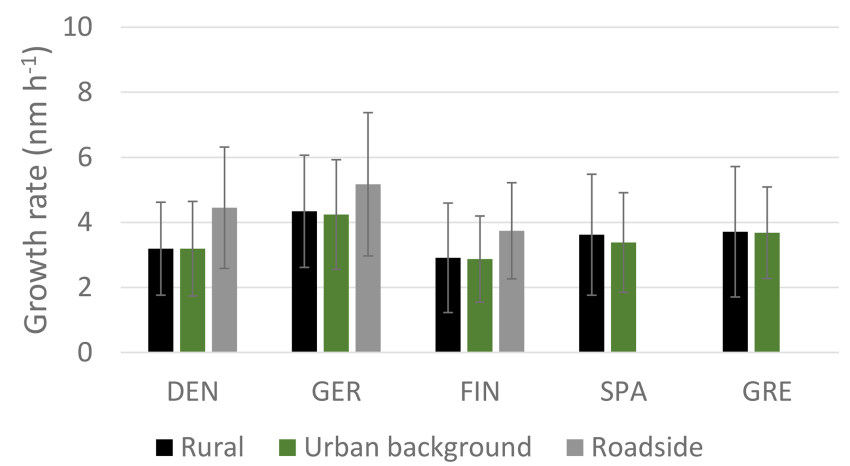

Figure 4. Growth rate of particles up to $30 \mathrm{~nm}$ (with standard deviations) during new particle formation events at all sites.

of the frequency of NPF events (the highest average for DENRO was found for winter, but it was only for a single event that occurred in that season). The formation rate $\left(J_{10}\right)$ was found to be broadly similar at the rural and urban background sites and higher at DENRO (Fig. 6), favoured by different seasons at each site (summer at DENRU, spring at DENUB, though with minimal differences and autumn at DENRO) (Fig. 7).

Similar to the frequency of NPF events, the German sites also had higher growth rates compared to sites of the same type in other areas of this study, with GERRU having $4.34 \pm 1.73 \mathrm{~nm} \mathrm{~h}^{-1}$, GERUB $4.24 \pm 1.69 \mathrm{~nm} \mathrm{~h}^{-1}$, and GERRO $5.17 \pm 2.20 \mathrm{~nm} \mathrm{~h}^{-1}$ (Fig. 3). While the difference between GERRU and GERUB is not statistically significant, there is a significant difference with GERRO $(p<0.005)$. Higher growth rates were found in summer compared to spring for all sites (Fig. 5). Specifically, for the roadside though, the highest average growth rates were found in autumn, which may be either a site-specific feature or an artefact of the limited number of events in that season (total of 11 NPF events in autumn). Similarly, $J_{10}$ at the German sites was also the highest among the sites of this study, increasing from the GERRU to GERRO. It was found to be higher in summer for the background sites and in autumn for GERRO.

For the Finnish sites, growth rates were similar at the background sites $\left(2.91 \pm 1.68 \mathrm{~nm} \mathrm{~h}^{-1}\right.$ at FINRU and $2.87 \pm$ $1.33 \mathrm{~nm} \mathrm{~h}^{-1}$ at FINUB), peaking in the summer months, similar to the findings of Yli-Juuti et al. (2011), while the peak for FINRO (growth rate at $3.74 \pm 1.48 \mathrm{~nm} \mathrm{~h}^{-1}$ ) was found in spring, though the differences between the seasons for this site were rather small. The formation rate was the highest at FINRO, peaking in autumn for both urban sites (with small differences with spring), while FINRU presented the highest $J_{10}$ in summer.

At the Spanish sites, the growth rate was similar for the two sites, being $3.62 \pm 1.86 \mathrm{~nm} \mathrm{~h}^{-1}$ at SPARU and $3.38 \pm$ $1.53 \mathrm{~nm} \mathrm{~h}^{-1}$ at SPAUB, again being higher in autumn for the urban site (which appears to be a feature of more polluted sites), while the rural site follows the general trend of rural

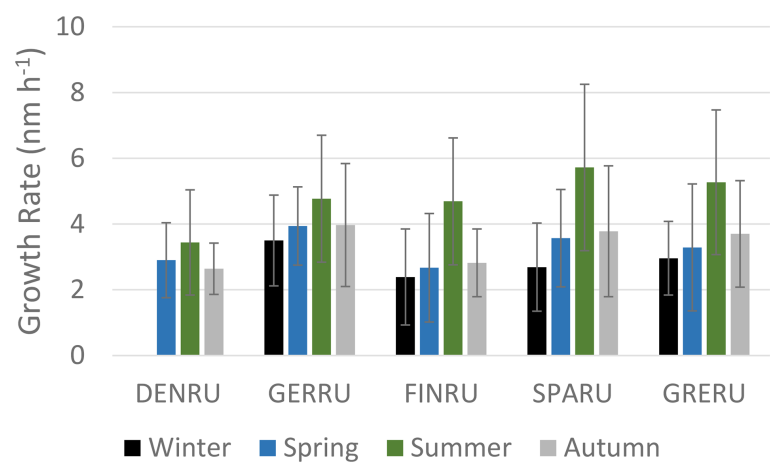

(a)

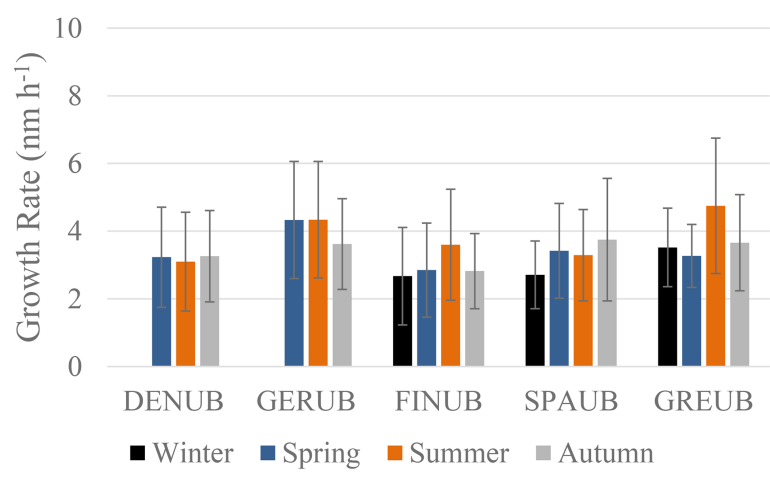

(b)

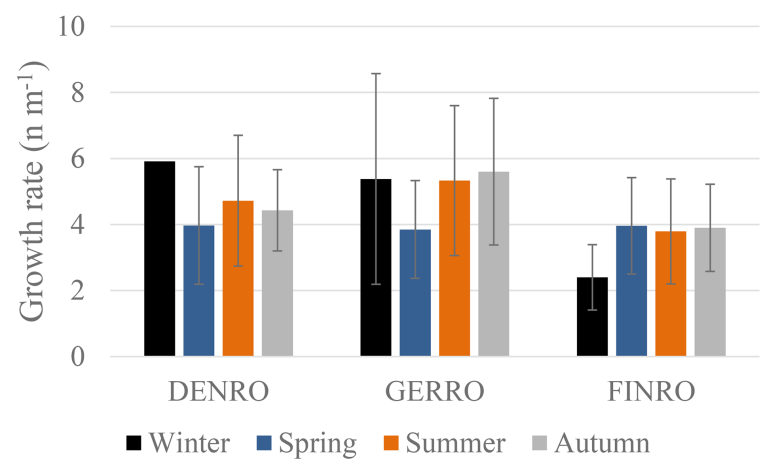

(c)

Figure 5. Seasonal variation of growth rate of particles up to $30 \mathrm{~nm}$ on new particle formation at (a) the rural background, (b) urban background, and (c) roadside sites.

background sites, peaking in summer. The formation rate at SPAUB is comparable to the other urban background sites (apart from GERUB) and peaked in spring, while once again the peak at SPARU was found in summer, similar to the other rural sites of this study apart from the Greek sites. At the urban site, both the growth and formation rates were higher on weekdays compared to weekends (both $p<0.001$ ). While the higher growth rate during weekdays may be associated with the increased presence of condensable species from anthropogenic activities, the higher formation rate might be affected by the increased emissions during these days, which bias to an extent its value. 


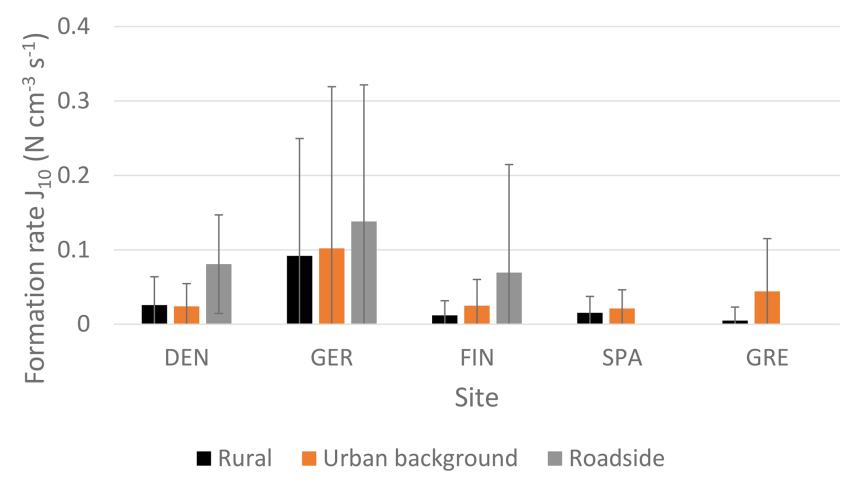

Figure 6. Formation rate of $10 \mathrm{~nm}$ particles $\left(J_{10}\right)$ (with standard deviations) from new particle formation at all sites.

Finally, the growth rate of particles was found to be similar at both Greek sites $\left(3.68 \pm 1.41 \mathrm{~nm} \mathrm{~h}^{-1}\right.$ for GREUB and $3.78 \pm 2.01 \mathrm{~nm} \mathrm{~h}^{-1}$ for GRERU) and was higher in summer compared to the other seasons, having a similar trend with the temperature and particulate organic carbon (OC) concentrations in the area. The formation rate presented a unique trend, having high averages in winter for both sites. Interestingly, contrary to most background sites in this study, the lowest average $J_{10}$ was found for summer at both sites.

\subsection{Conditions affecting NPF events}

The average and NPF event day conditions are presented in Tables S2 and S3 (for meteorological conditions and atmospheric composition respectively). A number of variables present consistent behaviour on NPF days. For all the sites in this study, the solar radiation intensity was higher on NPF days compared to the average conditions, while the relative humidity was lower. Additionally, all the chemical compounds with available data present either lower or similar concentrations. This is consistent, even for the chemical compounds which are associated with the NPF process (such as the $\mathrm{SO}_{2}$ ). This probably indicates that they are in sufficient concentrations for not being a limiting factor in the occurrence of the events, while higher concentrations are associated with increased pollution conditions which may suppress their occurrence. The exceptions found are SPARU and GRERU for $\mathrm{NO}_{2}$ and FINRU for $\mathrm{SO}_{2}$. At these sites, the concentrations of these gaseous components are very low in general (being rural background sites) and were found to be only marginally higher on NPF event days. These differences indicate that the variability of these compounds is not playing a significant role in the occurrence of the events and thus should not be considered an important factor. The ozone concentration, though, was found to be consistently higher on event days compared to the average conditions at all sites, regardless of their geographical location and type. As the ozone concentration variability is directly associated with the solar radiation intensity, it is unknown whether it plays a direct

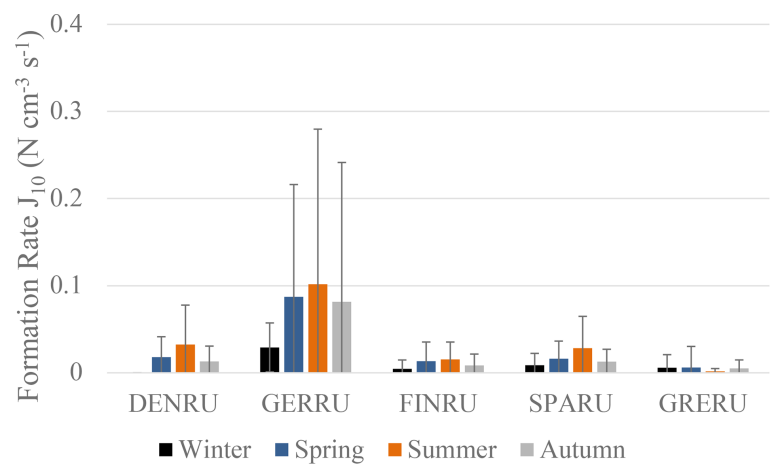

(a)

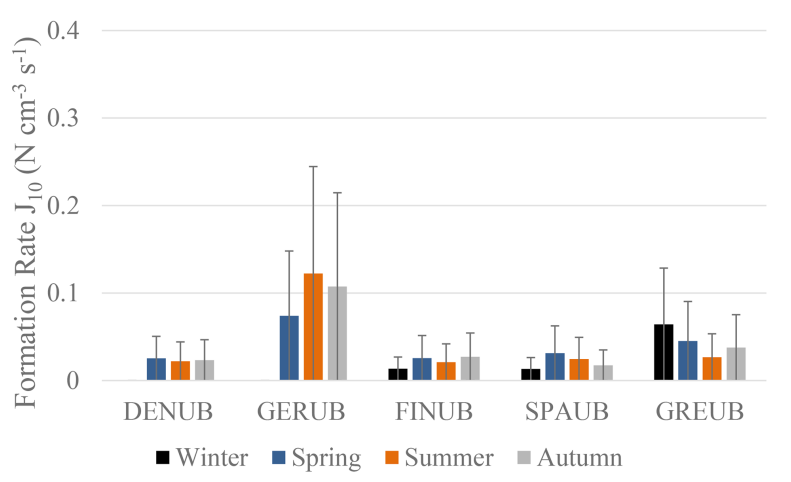

(b)

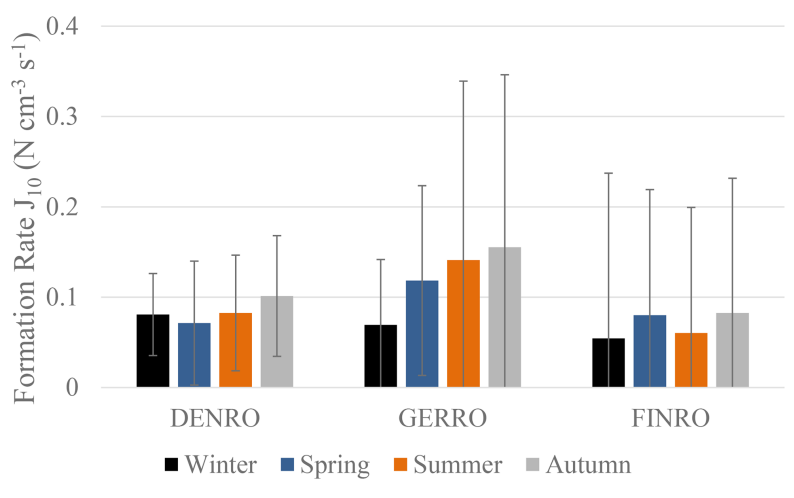

(c)

Figure 7. Seasonal variation of formation rate of $10 \mathrm{~nm}$ particles $\left(J_{10}\right)$ (with standard deviations) from new particle formation events at (a) the rural background, (b) urban background, and (c) roadside sites.

role in the occurrence of the events or it is the result of its covariance with the solar radiation intensity.

Following that, differences were found in the variability of some of the meteorological conditions, as well as local conditions (either meteorological or specific pollution sources), which played a significant role in the occurrence and the metrics of NPF events across the sites of this study. These will be further explored in the following sections. 


\subsubsection{Denmark}

The meteorological conditions that prevailed on NPF event days followed the general trend mentioned earlier, while wind speed and temperature were higher than average (consistently at all sites, meteorological condition variability was significant for all $(p<0.001)$ except the wind speed). As meteorological data were available from the urban background site (the variation between the rural and urban sites should not be great since they are about $25 \mathrm{~km}$ away from each other), the average conditions for the three sites are almost the same, with the only variability being the data availability among the sites. Thus, the more common wind directions in the area are southwesterly; for all sites though, the majority of NPF events are associated with direct westerly and northwesterly winds, similar to the findings of Wang et al. (2013) for the same site, which are those with the lowest concentrations of pollutants and condensation sink for all sites (Table S7), probably being of marine origin as elemental concentrations showed an increased presence of $\mathrm{Na}, \mathrm{Cl}$, and $\mathrm{Mg}$ (results not included). The wind directions with the highest probability for NPF events presented low growth rates and vice versa (Table $\mathrm{S} 4$ ), though it was proposed by Kristensson et al. (2008) that there is a possibility for events observed at the nearby Vavihill site in Sweden with northwesterly winds to be associated with the emissions of specific ship lanes that pass from that area. Wind direction sectors with higher concentrations of OC coincide with higher growth rates at DENRO, while this variability is not found at DENRU, possibly showing that different compounds and mechanisms take part in the growth process of the newly formed particles (Kulmala et al., 2004b).

As mentioned earlier, DENUB, although close to the DENRO site, has different seasonal variation of NPF events, with a marginally lower frequency in summer compared to the other two Danish sites, which have almost the same seasonal variation of NPF events. At DENUB, a strong presence of particles in the size range of about $50-60 \mathrm{~nm}$ is observed (Fig. S1 in the Supplement), especially during summer months, increasing the condensation sink in the area (this enhanced mode of particles is visible at DENRO as well, but its effect is dampened due to the elevated particle number concentrations in the other modes). This mode is probably part of the urban particle background. The strongest source though at DENUB appears to be from the east and consistently appears at both urban sites; this sector is where both elevated pollutant concentrations and condensation sink are found. In this sector, there are two possible local sources, either the port located $2 \mathrm{~km}$ to the east or the power plant located at a similar distance (or both). In general, both stations are located only a few kilometres away from the Øresund strait, a major shipping route. Studying the SMPS plots, it can be seen that NPF events at DENUB, especially in summer, tend to start but are either suppressed after the start or have a lifetime of a couple of hours before the new parti- cles are scavenged or evaporate. While this might explain to an extent the frequency and variability of NPF events at this site, the balance between the condensation sink and the concentration of condensable compounds is highlighted. While at DENRO the condensation sink is considerably higher than at DENUB and the effect of the aforementioned mode of particles is present at both, the occurrence and development of NPF events at DENRO are more pronounced in the data, due to the higher concentrations of condensable compounds.

\subsubsection{Germany}

Compared to the average conditions, a higher temperature was found on NPF event days, while wind speed was lower at all German sites. The condensation sink was also higher on event days compared to the average, though this may be the result of the high formation rates found for the German sites. The wind profile is different between the urban and the rural sites, with mainly northeasterly and southwesterly winds at the rural site and a more balanced profile for the urban sites. This difference is probably due to differences in the local topography. For the urban sites, the majority of NPF events are associated with easterly winds (to a lesser extent westerly as well for GERRO). At GERUB, along with the increased frequency of NPF events, the highest average growth rate is also found with easterly wind directions (though the differences are rather small). At GERRO, the frequency and growth rate appear to be affected by the topography of the site. Eisenbahnstraße is a road with an axis at almost 90 $270^{\circ}$, and although the $H / W$ ratio (surrounding building height to width ratio) is not high, the effect of a street canyon vortex is observed (Voigtländer et al., 2006). Possibly as a consequence of this, the probability of NPF events is low for direct northerly and southerly winds, although there are high growth rates of the newly formed particles (highest growth rates observed with southerly winds, associated with cleaner air).

At GERRU, an increased probability of NPF events and growth rate are also found for wind directions from the easterly sector, although these are not very frequent for this site. For this site chemical composition data for $\mathrm{PM}_{2.5}$ and $\mathrm{PM}_{10}$ are available, and it is found that the generally low (on average) concentrations of pollutants (such as elemental carbon (EC), nitrate, and sulfate) in general are elevated for wind directions from that sector. This is also reported for the Melpitz site (GERRU) by Jaatinen et al. (2009) and probably indicates that in a relatively clean area, the presence of low concentrations of pollutants may be favourable in the occurrence and development of NPF events, as in general, pollutant concentrations are lower on NPF event days compared to average conditions. Another interesting point is the concentration of organic carbon at the site (average of $2.18 \mu \mathrm{g} \mathrm{m}^{-3}$ in $\mathrm{PM}_{2.5}$ ), having the highest average concentration among the rural background sites studied. As other pollutant concentrations are relatively low at this site, it is possible that a portion 
of this organic carbon is of biogenic origin, considering also that the area is largely surrounded by forests and green areas, with a minimal effect of marine air masses (as indicated by the low marine component concentrations - data not included) and possibly pointing to increased presence of biogenic volatile organic compounds (BVOCs). The increased presence of organic species at GERRU may explain to some extent the increased frequency of NPF events, as well as the highest growth and formation rates found among the sites of this study.

\subsubsection{Finland}

At the background sites in Finland, temperature was lower on NPF event days compared to the average conditions, whereas it was higher for FINRO associated with the different seasonality of the events. No significant differences were found for the wind speed on NPF events for all sites. There are though some significant differences in the wind conditions for NPF events compared to average conditions. At FINRU, NPF events were more common with northerly wind directions, as was also found by Nieminen et al. (2014) and Nilsson et al. (2001). This is probably due to the lower condensation sink, which can be associated with the lower relative humidity also found for incoming winds from that sector and explains the lower temperatures found with NPF events at this site. Similarly, at FINUB, NPF events were favoured by wind directions from the northerly sector, while there is almost a complete lack of NPF on southerly winds. This is due to its position at the north of both the city centre and the harbour, though winds from that sector are not common in general for that site. Finally, the wind profile for NPF events at FINRO also favours northerly winds, with an almost complete absence of NPF in southerly winds, probably due to the elevated pollutant concentrations and condensation sink associated with them.

At all sites, NPF event days had a lower condensation sink compared to the average for the site. The seasonal variation of NPF events in Finland favouring spring was explained by earlier work as the result of the seasonal variation of $\mathrm{H}_{2} \mathrm{SO}_{4}$ concentrations (Nieminen et al., 2014), which in the area peak in spring. The variation of $\mathrm{H}_{2} \mathrm{SO}_{4}$ concentrations is directly associated with $\mathrm{SO}_{2}$ concentrations in the area, which follow a similar trend. The seasonal variation of NPF events at FINRO though cannot be explained by the variation of $\mathrm{H}_{2} \mathrm{SO}_{4}$ in the area. $\mathrm{SO}_{2}$ concentrations, which were available only for the nearby urban background site at Kalio (about $3 \mathrm{~km}$ away from FINRO) and may provide information upon the trends of $\mathrm{SO}_{2}$ in the greater area, peak during January (probably due to increased heating in winter and the limited oxidation processes due to lower incoming solar radiation) and are higher during spring months compared to summer. In general, the variation of pollutant concentrations and the condensation sink is not great for the spring and summer seasons. The only variable out of the ones considered that may explain to an extent the seasonality of NPF events at the site is the increased concentrations of $\mathrm{PM}_{10}$ found for spring months, which might be associated with road sanding and salting that takes place in Scandinavian countries during the colder months (Kupiainen et al., 2016), with emissions to the ambient air during spring months (Stojiljkovic et al., 2019). The source of these particles though is uncertain, as no major differences in the wind roses are found between the two seasons. Another study by Sarnela et al. (2015) at a different site in southern Finland attributed the seasonality of NPF events in Finland to the absence of $\mathrm{H}_{2} \mathrm{SO}_{4}$ clusters during summer months due to a possible lack of stabilizing agents (e.g. ammonia). This could explain the limited number of small particles (smaller than $10 \mathrm{~nm}$ ) at the background sites during summer. In the more polluted environment at a roadside site, these agents may exist, but such data were unfortunately not available.

Finally, a feature mentioned by Hao et al. (2018) in their study at the site of Hyytiälä, in which late particle growth is observed, was also found in this study. This happened on about $20 \%$ of NPF days at FINRU (and a number of nonevent days) and in most cases in early spring (before midApril) or late autumn (after mid-September). New particles were formed and either did not grow or grew very slowly until later in the day when growth rates increased (Fig. S2). In all these cases, growth started when solar radiation was very low or zero, which probably associates the growth of particles with night-time chemistry, leading to the formation of organonitrates (as found by the same study). A similar behaviour was also occasionally found at FINUB. Particle growth at late hours is not a unique feature for the Finnish sites, as it was found at all sites studied. What is different in the specific events is the lack of or very slow growth during the daytime. Lower temperature $\left(-0.81^{\circ} \mathrm{C}\right)$, incoming solar radiation $\left(112 \mathrm{~W} \mathrm{~m}^{-2}\right)$, and higher relative humidity $(68.4 \%)$ occurred on event days with later growth, while no clear wind association was found. Lower concentrations of organic matter and nitrate were found throughout the days with later growth compared to the rest of the NPF days. The very high average particle number concentration in the smaller size bins is due to particles, though not growing to larger sizes for some time, persisting in the local atmosphere for hours. These results though should be used with caution due to the limited number of observations.

\subsubsection{Spain}

The atmospheric conditions favouring NPF events at both sites are similar to most other sites, though with lower wind speed on event days compared to the average conditions $(p<0.001$ at SPAUB). The wind profile between the two sites is different, with mainly northwesterly and southeasterly winds for SPARU (which seems to be affected by the local topography), while a more balanced profile is found at SPAUB. For both sites, though, increased probability for 
NPF events is found for westerly and northwesterly winds. These incoming wind directions originate from a rather clean area with low concentrations of pollutants and condensation sink. At SPARU, incoming wind from directions with higher concentrations of pollutants and condensation sink was associated with a lower frequency of NPF events but higher growth rates. At SPAUB, NPF events were relatively rare, and growth rates were lower with easterly wind directions, as air masses originating from that section have passed from the city centre and the industrial areas from the Besos River. Due to this, incoming air masses from these sectors had higher concentrations of pollutants and condensation sink.

While NPF events with subsequent growth of the particles were rare during summer, cases of bursts of particles in the smallest size range available were found to occur frequently, especially in August and July (the month with the fewest NPF events, despite the favourable meteorological conditions). In such cases, a new mode of particles appears in the smallest size available, persisting for many hours, though without clear growth (brief or no growth is only observed), as reported by Dall'Osto et al. (2012). Due to the lack of growth of the particles, these burst events do not qualify as NPF events using the criteria set in the present study. These burst events are associated with southerly winds (known as garbí - southwest and migjorn - south in Catalan, which are common during the summer in the area) that bring a large number of particles smaller than $30 \mathrm{~nm}$ to the site from the nearby airport (located about $15 \mathrm{~km}$ to the southwest) and port (7 km south), as well as Saharan dust, increasing the concentrations of PM (Rodríguez et al., 2001) and thus suppressing NPF events due to the increased condensation sink.

Finally, the wind direction profile at SPARU appears to have a daily trend, with almost exclusively stronger southeasterly winds at about midday (Fig. S3), probably due to a local mesoscale circulation caused by the increased solar activity during that time (which results in different heating patterns of the various land types in the greater area). These incoming southeast winds are more polluted and have a higher condensation sink (being affected by the city of Barcelona) and almost consistently bring larger particles at the site during the midday period. This may explain to an extent the lowest probability for NPF events from that sector, despite the very high concentrations of $\mathrm{O}_{3}$ associated with them, with some extreme values well above $100 \mu \mathrm{g} \mathrm{m}^{-3}$ (Querol et al., 2017). The highest average growth rates are also found from that direction.

\subsubsection{Greece}

Temperature and wind speed are found to be lower on NPF event days at the Greek sites, though the differences are minimal and are associated with the seasonal variability of the events. The wind rose in GREUB mainly consists of northeasterly and southwesterly winds. Due to its position, the site is heavily affected by emissions in Athens city centre with westerly winds, resulting in increased particle number concentrations and condensation sink. Despite this, the highest NPF probability and growth rates were found with a northwesterly wind direction. This may be due to them being associated with the highest solar radiation (probably the result of seasonal and diurnal variation), temperature, and the lowest relative humidity, along with the highest condensation sink and particle number concentrations of almost all sizes. Chemical composition data were not available for GREUB, though $\mathrm{SO}_{2}$ concentrations are rather low in Athens and kept declining after the economic crisis (Vrekoussis et al., 2013). The seasonality of $\mathrm{SO}_{2}$ concentration in Athens favoured winter months and was at its lowest during summer for the period studied (YПЕКА, 2012) (this trend changed later as $\mathrm{SO}_{2}$ concentrations further declined), which may also be a factor in the seasonality of NPF events, though this will be further discussed later.

At the GRERU site, the wind profile is mainly westerly, and though it coincides with the most important source of pollutants in the area, the city of Heraklion, its effect while observable is not significant due to the topography in the area. The wind profile for NPF events is similar to the average, with significantly higher wind speeds $(p<0.001)$. In general, GRERU has very low pollutant concentrations, with an average NO of $0.073 \mu \mathrm{g} \mathrm{m}^{-3}, \mathrm{NO}_{2}$ of $0.52 \mu \mathrm{g} \mathrm{m}^{-3}$, and $\mathrm{SO}_{2}$ of concentrations below $1 \mathrm{ppb}$ (Kouvarakis et al., 2002). Due to this, the differences in the chemical composition in the atmosphere are also minimal. For the specific site, two different patterns of development of NPF events were found. In one case, NPF events occurred in a rather clear background, while in the other one, they were accompanied with an increase in number concentrations of larger particles or a new mode appearing at larger sizes (about a third of the events). No differences were found in the seasonal variation between the two groups; increased gaseous pollutant and particulate organic carbon concentrations were found for the second group (though the differences were rather small) and a wind rose that favoured southwesterly winds (originating from mainland Crete) instead of the northwesterly (originating from the sea) ones for the first group. The growth rate for the two groups was found to be $3.56 \mathrm{~nm} \mathrm{~h}^{-1}$ for the first group and $4.17 \mathrm{~nm} \mathrm{~h}^{-1}$ for the second, which might be due to the increased presence of condensable compounds. As the dataset starts from the particle size of $8.77 \mathrm{~nm}$, the possibility that these particles were advected from nearby areas should not be overlooked, though they persisted and grew at the site. Other than that, no significant differences were found for the different wind directions.

As mentioned earlier, both sites had a very low frequency of events and $J_{10}$ in summer, similar to previous studies also reporting few or no events during summer (Vratolis et al., 2019; Ždímal et al., 2011), though the incoming solar radiation is the highest and relative humidity is the lowest during that season. This variation was also observed by Kalivitis et al. (2012), who associated the seasonal variation of NPF 
events at GRERU with the concentrations of atmospheric ions. The effect of the Etesian winds (known as meltemia in Greek), which dominate the southern Aegean region during the summer months, though, should not be overlooked. These result in very strong winds, with an average wind speed of $8.15 \mathrm{~m} \mathrm{~s}^{-1}$ during summer at the Finokalia site, and increased turbulence found in all years with available data, affecting both sites of this study. During this period, $N_{<30 \mathrm{~nm}}$ drops to half or less compared to other seasons at both sites, while $N_{>100 \mathrm{~nm}}$ is at its maximum due to particle ageing (Kalkavouras et al., 2017), increasing the condensation sink, especially in GRERU (the effect in GREUB is less visible due to both the wind profile, blowing from the east, which is a less polluted area, as well as the reduction of urban activities during summer months in Athens). Both the increased condensation sink and turbulence are possible factors for the reduced number of NPF events found at both sites in summer. Another possible factor is the effect of high temperatures in destabilizing the molecular clusters critical to new particle formation.

\subsection{Region-wide events}

Region-wide events are NPF events which occur over largescale areas, that may cover hundreds of kilometres (Shen et al., 2018). In the present study, NPF events that took place on the same day at both background sites (urban background and rural) are considered regional, and their conditions are studied (Table S8). The background sites in Greece were not considered due to the great distance between them (about $350 \mathrm{~km}$ ). There is also uncertainty for the background sites in Finland, where the distance is about $190 \mathrm{~km}$, though a large number of days were found when NPF events occurred on the same day. The number of region-wide events per season (or the fraction of region-wide events to total NPF events) is found in Fig. 8, and it appears as if they are more probable in spring at all the sites of the present study (apart from Finland, though the number of events in winter was low), despite the differences found in absolute numbers.

In Denmark, about $20 \%$ of NPF events in DENRU were regional (the percentage is higher for DENUB due to the smaller number of events, at $29 \%$ ). The relatively low frequency of region-wide NPF events can be explained by the different seasonal dependence of NPF events (region-wide NPF events were more frequent in spring compared to the average due to the seasonality of NPF events in DENUB). Compared to local NPF event conditions, higher wind speed and solar radiation, as well as $\mathrm{O}_{3}$ and marine compound concentrations (results not included) were found, while the concentrations of all pollutants (such as $\mathrm{NO}, \mathrm{NO}_{x}$, sulfate, elemental carbon, and organic carbon) were lower. These cleaner atmospheric conditions are also confirmed by the lower CS associated with region-wide events, which is probably one of the most important factors in the occurrence of these large-scale events. The exceptions found at DENRU

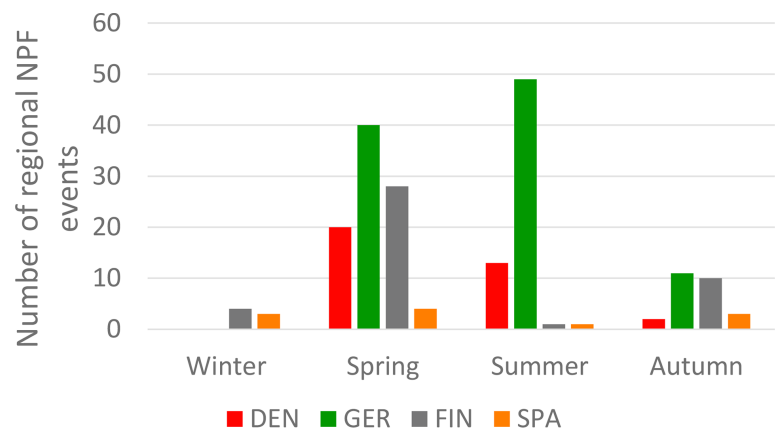

(a)

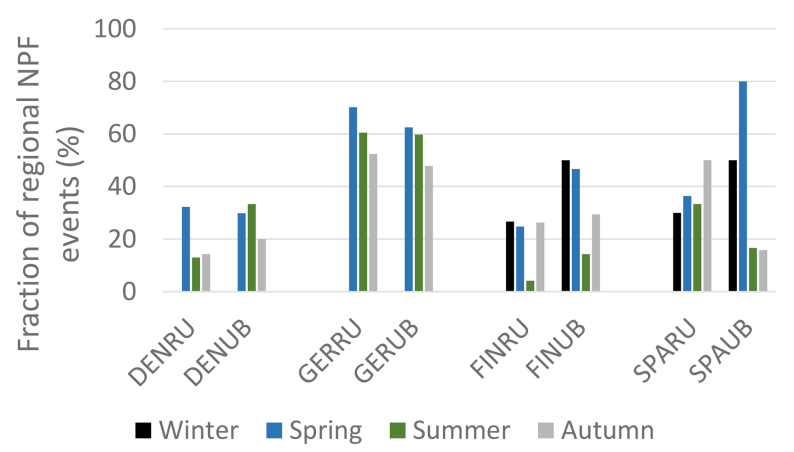

(b)

Figure 8. (a) Number of region-wide new particle formation events per season and (b) fraction of region-wide events to total new particle formation events per season for each site. Region-wide events are considered those that occur on the same day at both background sites (rural and urban background).

(increased relative humidity and less incoming solar radiation) are probably due to the different seasonality between local and region-wide NPF events at the site, though regionwide events rarely present similar characteristics at different sites, even in the same country, due to the differences in the initial meteorological and local conditions (Hussein et al., 2009). The growth rates of region-wide events were found to be lower than those of local events at both sites, which is probably associated with the limited concentrations of condensable compounds due to the cleaner air masses of marine origin (as confirmed by the higher concentrations of marine compounds).

In Germany, the majority of NPF events of this study were region-wide (about $60 \%$ ). Compared to the average, the meteorological conditions found for NPF event days compared to average conditions were more distinct for the region-wide events, with even lower wind speed and relative humidity and higher temperature and solar radiation, and all of these differences were significant $(p<0.001)$. At GERRU, where chemical composition data were available, higher concentrations of particulate organic carbon and sulfate and lower nitrate concentrations were found. The differences are significant $(p<0.001)$ and may explain the higher growth rates found in region-wide events at both sites compared to the av- 
erage, which is a unique feature. It should be noted that as the majority of NPF events at the German sites are associated with easterly winds, it is expected that in most cases the region-wide events will be associated with these, carrying the characteristics that come along with them (increased growth rates and concentrations of organic carbon, as discussed in Sect. 3.2).

In Finland, about a quarter of the NPF event days at FINRU (26\%) occurred on the same day as at FINUB (the frequency is a lot higher for FINUB, at 39\%). As in Germany, the meteorological conditions found on NPF event days compared to average conditions were more distinct during region-wide events. Thus, for both sites, temperature and relative humidity were lower, while solar radiation was higher. The different trend found for the wind speed at the two sites (being higher on average NPF days at FINRU and lower at FINUB compared to average conditions) was enhanced as well at the two sites for region-wide events. At FINRU where chemical composition data were available, $\mathrm{NO}_{x}$ and $\mathrm{SO}_{2}$ had similar concentrations on region-wide event days compared to the averages on total event days, while $\mathrm{O}_{3}$ was significantly higher $(p<0.001)$. As at most other sites, the growth rate was found lower on region-wide event days compared to the average at both sites.

Finally, in Spain, the datasets of the two sites did not overlap greatly, having only 322 common days. Among these days, $13 \mathrm{~d}$ presented with NPF events that took place simultaneously at both sites, with smaller growth rates on average compared to local events (43\% of the events at SPARU and $36 \%$ of the events at SPAUB in the period August 2012 to January 2013 and 2014 when data for both sites were available). Due to the small number of common events, the results are quite mixed, with the only consistent result being the lower relative humidity and higher $\mathrm{O}_{3}$ concentrations for regional events at both sites, though none of these differences is significant. The wind profile at SPAUB seems to further favour the cleaner sector, with the majority of incoming winds being from the NW and even higher wind speeds (though with low significance). The result is similar at SPARU, though less clear and with lower wind speeds.

These results are in general in agreement with those found in the UK in a previous study, where meteorological conditions were more distinct on region-wide event days compared to local NPF events; pollutant concentrations were lower as well as the growth rates of the newly formed particles (Bousiotis et al., 2019).

Common events were also found between either of the background sites and the roadside, but they were always fewer in number, due to the difference in their temporal variability compared to the background sites, resulting from the effect of roadside pollution.

\subsection{The effect of NPF events on the ultrafine particle concentrations}

The NSF is a metric of the effect of NPF events upon particle concentrations on either the days of the events or over a larger timescale. Both the $\mathrm{NSF}_{\mathrm{NUC}}$ and $\mathrm{NSF}_{\mathrm{GEN}}$ were calculated for all sites of this study, and the results are presented in Fig. 9. For almost all rural background sites, $\mathrm{NSF}_{\mathrm{NUC}}$, which indicates the effect of NPF on ultrafine particle concentrations on the day of the event, was found to be greater than 2 (the only exception was GERRU), which means that NPF events more than double the number of ultrafine particles (particles with diameter smaller than $100 \mathrm{~nm}$ ) at the site on the days of the events, as NPF events are one of the main sources of ultrafine particles at this type of site, especially below $30 \mathrm{~nm}$. This reaches up to 4.18 found at FINRU $(418 \%$ more ultrafine particles on the day of the events $-100 \%$ being the average), showing the great effect NPF events have on rather clean areas. The long-term effect was smaller, and it was found that at FINRU NPF events increase the number of ultrafine particles by an additional $130 \%$ in general. The effect of NPF events was a lot smaller at the urban sites, though still significant at urban background sites (reaching up $240 \%$ at FINUB on the days of events), while roadsides had the smallest NSF compared to their respective background sites. This is because of the increased effect of local sources such as traffic or heating and the associated increased condensation sink found at these sites, which cause the new particles to be scavenged by the more polluted background.

The calculation of NSF at the sites around Europe showed a weakness of the specific metric, which points to the need for more careful interpretation of the results of this metric, especially at roadside sites. At FINRO, the $\mathrm{NSF}_{\mathrm{NUC}}$ provided a value smaller than 1 , which translates as ultrafine particles being lost instead of formed on NPF event days. This though is the result of both the sharp reduction in particle number concentrations at all modes that are required for NPF events to occur at a busy roadside (much lower condensation sink) and a difference in the ratio between smaller and larger particles (smaller or larger than $100 \mathrm{~nm}$ ) on NPF event days (favouring the larger particles) at the specific site. Similarly, the long-term effect of NPF events at the site was found to be 1, which means that NPF events appear to cause no changes in the number concentration of ultrafine particles.

\section{Discussion}

\subsection{Variability of the frequency and seasonality of the events}

A higher frequency of NPF events at the rural background sites compared to roadsides was found for all countries with available data for both types of site. This pattern comes in contrast with what was found for the more polluted Asian 


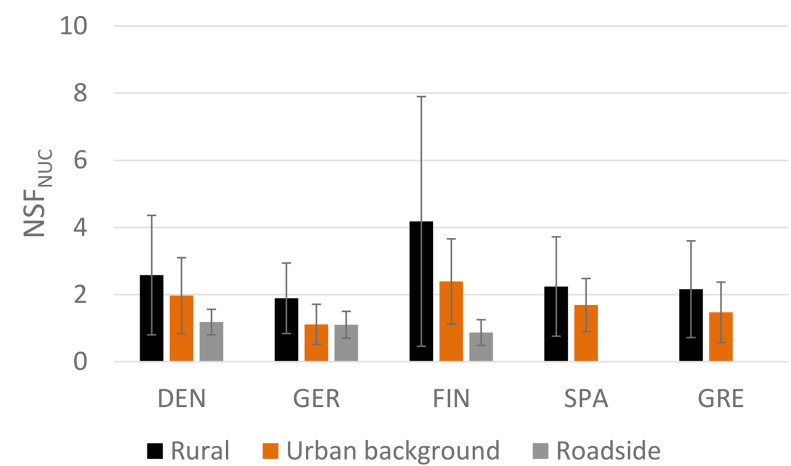

(a)

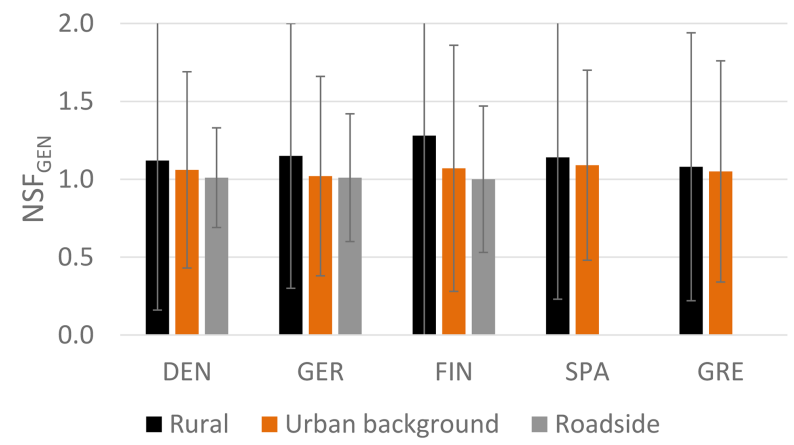

(b)

Figure 9. (a) $\mathrm{NSF}_{\mathrm{NUC}}$ (average relative increase of ultrafine particles - particles of diameter up to $100 \mathrm{~nm}$ ) due to new particle formation events on event days) and (b) $\mathrm{NSF}_{\mathrm{GEN}}$ (average annual relative increase of ultrafine particles due to new particle formation events) at all sites.

cities (Peng et al., 2017; Wang et al., 2017), where NPF events were more frequent at the urban sites. This is probably associated with the even greater abundance of condensable species (which further enhances the growth of the particles, thus increasing their chance of survival), deriving from anthropogenic emissions, found in Asian megacities compared to European ones and results in a greater frequency of NPF events in Asian cities, even compared to the most polluted cities in Europe. This contrast emphasizes the differences in the occurrence of NPF events between the polluted cities in Europe and Asia, which are associated with the level of pollution found in them, as well as the influence that the level of pollution has on the occurrence of NPF events in general.

The type of site dependence found in Europe, together with the average conditions found on NPF event days compared to the average for each site, underlines the importance of clear atmospheric conditions (high solar radiation and low relative humidity and pollutant concentrations) at all types of sites in Europe, especially for region-wide events. The temperature and wind speed presented more diverse results, which in many cases are associated with local conditions. The origin of the incoming air masses, though, appears to have a more important influence upon the NPF events. Cleaner air masses tend to have higher probability for NPF events, a result which was consistent among the sites of this study, regardless of their type.

The frequency of NPF events at roadsides peaked in summer in all three countries with available data. Greater variability in the seasonality of NPF events was found at the background sites. The urban background sites presented more diverse results, for both the occurrence and development of NPF events, especially compared to rural background sites. The within-week variation of NPF events was found to favour weekends in most cases, as the pollution levels decrease, due to the weekly cycle, especially at the roadsides. As background sites have smaller variations between weekdays and weekends, the within-week variation of NPF events is smaller at the urban background sites and almost non-existent at the rural background sites. Finally, it should be noted that no clear interannual trend was found in the frequency of the events for any site, even for those with longer datasets.

\subsection{Variability and seasonality of the formation and growth rate}

The growth rate of the newly formed particles was found to be higher at all the roadsides compared to their respective rural and urban background. The picture is similar for $J_{10}$ (the rate of formed particles associated with NPF events that reached $10 \mathrm{~nm}$ diameter), for which urban background sites were between their respective rural background sites and the roadsides with the sole exception of DENUB (the difference with DENRU is rather small though). The growth and formation rate at the rural background sites (apart from the Greek site) were found to be higher in summer compared to the other seasons. On the other hand, the seasonality of the growth rate at the roadsides is not clear, but the formation rate peaks in the autumn at all three roadside sites. While the trend at the rural sites is probably associated with the enhanced photochemistry and increased concentrations of BVOCs during summer, the seasonality of the growth rate at the roadside sites is more difficult to explain and probably shows the smaller importance of the BVOCs compared to the compounds of anthropogenic origin (which are in less abundance in summer) in this type of environment. In general, higher temperatures were associated with higher growth rates. This though applies only for the specific conditions at each site and cannot be used as a general rule for the expected growth rate at a site, as locations with higher temperatures did not present higher growth rates. Additionally, the origin of the incoming air masses appears to have an effect on the growth of the particles as well. At most of the sites in this study, incoming air masses from directions associated with higher concentrations of pollutants presented higher growth rates of the newly formed particles. The effect of the different wind directions upon the formation rate was more complex, and a definitive conclusion cannot be made. Finally, as with the frequency of the events, no significant interannual trend 
was found in the variation of the formation or the growth rate across the sites studied.

\subsection{Effect of local conditions in the occurrence and development of NPF events}

Apart from the general meteorological and atmospheric conditions that affect the occurrence and the metrics of NPF events, conditions with a more local character were found to play a significant role as well. These include synoptic systems, such as the one occurring during the summer at the Greek sites, affecting the frequency and seasonality of the events. As a result, sites or seasons with conditions that favoured NPF presented decreased frequency of events and unexpected seasonality, due to the increased turbulence caused by such pressure systems. Additionally, local sources of pollution can also have a significant impact on the temporal trends and metrics of the events, even for sites of very close proximity. One such example was the urban sites in Denmark, which, despite being affected by the same source of pollution (the nearby port) and being only a few kilometres away from each other, presented different outcomes in the occurrence of the events. This was due to the different atmospheric composition found between them, being a background and a roadside site, which led to a different response in that local variable. In this case, the effect of the specific source was more prominent at the urban background site compared to the roadside, resulting in fewer NPF events, as the newly formed particles were more effectively suppressed at the urban background site, due to their slower growth.

\section{Conclusions}

There are different ways to assess the occurrence of new particle formation (NPF) events. In this study, the frequency of NPF events, the formation and growth rate of the particles associated with secondary formation of particles and not primary emissions, at 13 sites from five countries in Europe are considered. NPF is a complicated process, affected by many meteorological and environmental variables. The seasonality of these variables, which varies throughout Europe, results in the different temporal trends found for the metrics studied in this paper. Apart from meteorological conditions though, some of which have a uniform effect (such as the solar radiation intensity and relative humidity), many local variables can also have a positive or negative effect in the occurrence of these events. Sites with less anthropogenic influence seem to have temporal trends dependent on the seasonality of synoptic conditions and general atmospheric composition. The urban sites, though, and especially those with significant sources of pollution in close proximity, present more complex trends as the NPF occurrence depends less upon favourable meteorological conditions and more upon the local atmospheric conditions, including composition. As
NPF event occurrence is based on the balance between the rapid growth of the newly formed particles and their loss from processes, such as the evaporation or coagulation of the particles, the importance of significant particle formation, fast growth (which is enhanced by the increased presence of condensable compounds from anthropogenic activities found in urban environments), and low condensation sink is increased within such environments, also affecting the temporal trends of the events, making them more probable during periods with smaller pollution loads (e.g. summer, weekends). This explains the smaller frequency of NPF events at roadside sites compared to their respective background sites, despite the greater formation and growth rates observed in them. Consequently, NPF events have a smaller influence on the ultrafine particle load at the urban sites compared to background sites, due to both the increased presence of ultrafine particles from anthropogenic emissions and the smaller probability of ultrafine particles to survive in such environments.

Nevertheless, NPF events are an important source of ultrafine particles in the atmosphere for all types of environment and are an important factor in the air quality of a given area. The present study underlines the importance of both the synoptic and local conditions on NPF events, the mix of which not only affects their development, but can also influence their occurrence, even in areas of very close proximity. NPF is a complex process, affected by numerous variables, making it extremely difficult to predict any of its metrics without considering multiple factors. Since the mechanisms and general trends in NPF events are yet to be fully explained and understood, more laboratory and field studies are needed to generate greater clarity and predictive capability.

Data availability. Data supporting this publication are openly available from the UBIRA eData repository at https://doi.org/10.25500/edata.bham.00000467 (Harrison and Bousiotis, 2020).

Supplement. The supplement related to this article is available online at: https://doi.org/10.5194/acp-21-11905-2021-supplement.

Author contributions. The study was conceived and planned by $\mathrm{MDO}$ and RMH, who also contributed to the final paper. The data analysis was carried out by $\mathrm{DB}$, who also prepared the first draft of the manuscript. AM, JKN, CN, JVN, HP, NP, AA, GK, SV, and KE provided the data for the analysis. FDP, XQ, DCSB, and TP provided advice on the analysis.

Competing interests. The authors declare that they have no conflict of interest. 
Disclaimer. Publisher's note: Copernicus Publications remains neutral with regard to jurisdictional claims in published maps and institutional affiliations.

Financial support. This research has been supported by the National Centre for Atmospheric Science funded by the U.K. Natural Environment Research Council (R8/H12/83/011).

Review statement. This paper was edited by Neil M. Donahue and reviewed by three anonymous referees.

\section{References}

Aalto, P., Hämeri, K., Becker, E. D. O., Weber, R., Salm, J., Mäkelä, J. M., Hoell, C., O’Dowd, C. D., Karlsson, H., Hansson, H., Väkevä, M., Koponen, I. K., Buzorius, G., and Kulmala, M.: Physical characterization of aerosol particles during nucleation events, Tellus B, 53, 344-358, https://doi.org/10.3402/tellusb.v53i4.17127, 2001.

Alam, A., Shi, J. P., and Harrison, R. M.: Observations of new particle formation in urban air, J. Geophys. Res.-Atmos., 108, 4093, https://doi.org/10.1029/2001JD001417, 2003.

Atkinson, R. W., Fuller, G. W., Anderson, H. R., Harrison, R. M., and Armstrong, B.: Urban ambient particle metrics and health: A time-series analysis, Epidemiology, 21, 501-511, https://doi.org/10.1097/EDE.0b013e3181debc88, 2010.

Bianchi, F., Kurtén, T., Riva, M., Mohr, C., Rissanen, M. P., Roldin, P., Berndt, T., Crounse, J. D., Wennberg, P. O., Mentel, T. F., Wildt, J., Junninen, H., Jokinen, T., Kulmala, M., Worsnop, D. R., Thornton, J. A., Donahue, N., Kjaergaard, H. G., and Ehn, M.: Highly oxygenated organic molecules (HOM) from gas-phase autoxidation involving peroxy radicals: A key contributor to atmospheric aerosol, Chem. Rev., 119, 3472-3509, https://doi.org/10.1021/acs.chemrev.8b00395, 2019.

Birmili, W., Weinhold, K., Rasch, F., Sonntag, A., Sun, J., Merkel, M., Wiedensohler, A., Bastian, S., Schladitz, A., Löschau, G., Cyrys, J., Pitz, M., Gu, J., Kusch, T., Flentje, H., Quass, U., Kaminski, H., Kuhlbusch, T. A. J., Meinhardt, F., Schwerin, A., Bath, O., Ries, L., Gerwig, H., Wirtz, K., and Fiebig, M.: Longterm observations of tropospheric particle number size distributions and equivalent black carbon mass concentrations in the German Ultrafine Aerosol Network (GUAN), Earth Syst. Sci. Data, 8, 355-382, https://doi.org/10.5194/essd-8-355-2016, 2016.

Bousiotis, D., Dall'Osto, M., Beddows, D. C. S., Pope, F. D., and Harrison, R. M.: Analysis of new particle formation (NPF) events at nearby rural, urban background and urban roadside sites, Atmos. Chem. Phys., 19, 5679-5694, https://doi.org/10.5194/acp19-5679-2019, 2019.

Boy, M., Kulmala, M., Ruuskanen, T. M., Pihlatie, M., Reissell, A., Aalto, P. P., Keronen, P., Dal Maso, M., Hellen, H., Hakola, H., Jansson, R., Hanke, M., and Arnold, F.: Sulphuric acid closure and contribution to nucleation mode particle growth, Atmos. Chem. Phys., 5, 863-878, https://doi.org/10.5194/acp-5863-2005, 2005.

Brean, J., Harrison, R. M., Shi, Z., Beddows, D. C. S., Acton, W. J. F., Hewitt, C. N., Squires, F. A., and Lee, J.: Observations of highly oxidized molecules and particle nucleation in the atmosphere of Beijing, Atmos. Chem. Phys., 19, 14933-14947, https://doi.org/10.5194/acp-19-14933-2019, 2019.

Brines, M., Dall'Osto, M., Beddows, D. C. S., Harrison, R. M., and Querol, X.: Simplifying aerosol size distributions modes simultaneously detected at four monitoring sites during SAPUSS, Atmos. Chem. Phys., 14, 2973-2986, https://doi.org/10.5194/acp14-2973-2014, 2014.

Brines, M., Dall'Osto, M., Beddows, D. C. S., Harrison, R. M., Gómez-Moreno, F., Núñez, L., Artíñano, B., Costabile, F., Gobbi, G. P., Salimi, F., Morawska, L., Sioutas, C., and Querol, X.: Traffic and nucleation events as main sources of ultrafine particles in high-insolation developed world cities, Atmos. Chem. Phys., 15, 5929-5945, https://doi.org/10.5194/acp15-5929-2015, 2015.

Carnerero, C., Pérez, N., Reche, C., Ealo, M., Titos, G., Lee, H.K., Eun, H.-R., Park, Y.-H., Dada, L., Paasonen, P., Kerminen, V.-M., Mantilla, E., Escudero, M., Gómez-Moreno, F. J., Alonso-Blanco, E., Coz, E., Saiz-Lopez, A., Temime-Roussel, B., Marchand, N., Beddows, D. C. S., Harrison, R. M., Petäjä, T., Kulmala, M., Ahn, K.-H., Alastuey, A., and Querol, X.: Vertical and horizontal distribution of regional new particle formation events in Madrid, Atmos. Chem. Phys., 18, 16601-16618, https://doi.org/10.5194/acp-18-16601-2018, 2018.

Charron, A., Birmili, W., and Harrison, R. M.: Fingerprinting particle origins according to their size distribution at a UK rural site, J. Geophys. Res.-Atmos., 113, 1-15, https://doi.org/10.1029/2007JD008562, 2008.

Cheung, H. C., Chou, C. C.-K., Huang, W.-R., and Tsai, C.Y.: Characterization of ultrafine particle number concentration and new particle formation in an urban environment of Taipei, Taiwan, Atmos. Chem. Phys., 13, 8935-8946, https://doi.org/10.5194/acp-13-8935-2013, 2013.

Chu, B., Kerminen, V.-M., Bianchi, F., Yan, C., Petäjä, T., and Kulmala, M.: Atmospheric new particle formation in China, Atmos. Chem. Phys., 19, 115-138, https://doi.org/10.5194/acp-19-1152019, 2019.

Costabile, F., Birmili, W., Klose, S., Tuch, T., Wehner, B., Wiedensohler, A., Franck, U., König, K., and Sonntag, A.: Spatiotemporal variability and principal components of the particle number size distribution in an urban atmosphere, Atmos. Chem. Phys., 9, 3163-3195, https://doi.org/10.5194/acp-9-3163-2009, 2009.

Dall'Osto, M., Beddows, D. C. S., Pey, J., Rodriguez, S., Alastuey, A., Harrison, R. M., and Querol, X.: Urban aerosol size distributions over the Mediterranean city of Barcelona, NE Spain, Atmos. Chem. Phys., 12, 10693-10707, https://doi.org/10.5194/acp-12-10693-2012, 2012.

Dall'Osto, M., Querol, X., Alastuey, A., O'Dowd, C., Harrison, R. M., Wenger, J., and Gómez-Moreno, F. J.: On the spatial distribution and evolution of ultrafine particles in Barcelona, Atmos. Chem. Phys., 13, 741-759, https://doi.org/10.5194/acp-13-7412013, 2013.

Dall'Osto, M., Beddows, D. C. S., Asmi, A., Poulain, L., Hao, L., Freney, E., Allan, J. D., Canagaratna, M., Crippa, M., Bianchi, F., De Leeuw, G., Eriksson, A., Swietlicki, E., Hansson, H. C., Henzing, J. S., Granier, C., Zemankova, K., Laj, P., Onasch, T., Prevot, A., Putaud, J. P., Sellegri, K., Vidal, M., Virtanen, A., Simo, R., Worsnop, D., O’Dowd, C., Kulmala, M., and Harri- 
son, R. M.: Novel insights on new particle formation derived from a pan-european observing system, Sci. Rep.-UK, 8, 1-11, https://doi.org/10.1038/s41598-017-17343-9, 2018.

Dal Maso, M., Kulmala, M., Lehtinen, K. E. J., Mäkelä, J. M., Aalto, P., and O'Dowd, C. D.: Condensation and coagulation sinks and formation of nucleation mode particles in coastal and boreal forest boundary layers, J. Geophys. Res.-Atmos., 107, PAR 2-1-PAR 2-10, https://doi.org/10.1029/2001JD001053, 2002.

Dal Maso, M., Kulmala, M., Riipinen, I., Wagner, R., Hussein, T., Aalto, P. P., and Lehtinen, K. E. J.: Formation and growth of fresh atmospheric aerosols: Eight years of aerosol size distribution data from SMEAR II, Hyytiälä, Finland, Boreal Environ. Res., 10, 323-336, https://doi.org/10.1016/j.ijpharm.2012.03.044, 2005.

Dameto de España, C., Wonaschütz, A., Steiner, G., Rosati, B., Demattio, A., Schuh, H., and Hitzenberger, R.: Long-term quantitative field study of New Particle Formation (NPF) events as a source of Cloud Condensation Nuclei $(\mathrm{CCN})$ in the urban background of Vienna, Atmos. Environ., 164, 289-298, https://doi.org/10.1016/j.atmosenv.2017.06.001, 2017.

Deng C., Fu, F., Dada, L., Yan, C., Cai, R., Yang, D., Zhou, Y., Yin, R., Lu, Y., Li, X., Fan, X., Nie, W., Kontkanen, J., Kangasluoma, J., Chu, B., Ding, A., Kerminen, V.-M., Paasonen, P., Worsnop, D.R., Bianchi, F., Liu, Y., Zheng, J., Wang, L., Kulmala, M., and Jiang, J.: Seasonal Characteristics of New Particle Formation and Growth in Urban Beijing, Environ. Sci. Technol., 54, 8547-8557, 2020.

Ehn, M., Thornton, J. A., Kleist, E., Sipilä, M., Junninen, H., Pullinen, I., Springer, M., Rubach, F., Tillmann, R., Lee, B., Lopez-Hilfiker, F., Andres, S., Acir, I. H., Rissanen, M., Jokinen, T., Schobesberger, S., Kangasluoma, J., Kontkanen, J., Nieminen, T., Kurtén, T., Nielsen, L. B., Jørgensen, S., Kjaergaard, H. G., Canagaratna, M., Maso, M. D., Berndt, T., Petäjä, T., Wahner, A., Kerminen, V. M., Kulmala, M., Worsnop, D. R., Wildt, J., and Mentel, T. F.: A large source of lowvolatility secondary organic aerosol, Nature, 506, 476-479, https://doi.org/10.1038/nature13032, 2014.

Fuchs, N. A. and Sutugin, A. G.: Highly dispersed aerosols, Foreign Sci. Technol. Center, 1-86, 1971.

Hama, S. M. L., Cordell, R. L., Kos, G. P. A., Weijers, E. P., and Monks, P. S.: Sub-micron particle number size distribution characteristics at two urban locations in Leicester, Atmos. Res., 194, 1-16, https://doi.org/10.1016/j.atmosres.2017.04.021, 2017.

Hao, L., Garmash, O., Ehn, M., Miettinen, P., Massoli, P., Mikkonen, S., Jokinen, T., Roldin, P., Aalto, P., Yli-Juuti, T., Joutsensaari, J., Petäjä, T., Kulmala, M., Lehtinen, K. E. J., Worsnop, D. R., and Virtanen, A.: Combined effects of boundary layer dynamics and atmospheric chemistry on aerosol composition during new particle formation periods, Atmos. Chem. Phys., 18, 1770517716, https://doi.org/10.5194/acp-18-17705-2018, 2018.

Harrison, R. M. and Bousiotis, D.: Meteorological conditions and atmospheric composition data from 13 sites in Europe, University of Birmingham [data set], https://doi.org/10.25500/edata.bham.00000467, 2020.

Harrison, R. M., Shi, J. P., Xi, S., Khan, A., Mark, D., Kinnersley, R., and Yin, J.: Measurement of number, mass and size distribution of particles in the atmosphere, Philos. T. R. Soc. A, 358, 2567-2580, https://doi.org/10.1098/rsta.2000.0669, 2000.
Hietikko, R., Kuuluvainen, H., Harrison, R. M., Portin, H., Timonen, H., Niemi, J. V., and Rönkkö, T.: Diurnal variation of nanocluster aerosol concentrations and emission factors in a street canyon, Atmos. Environ., 189, 98-106, https://doi.org/10.1016/j.atmosenv.2018.06.031, 2018.

Hofman, J., Staelens, J., Cordell, R., Stroobants, C., Zikova, N., Hama, S. M. L., Wyche, K. P., Kos, G. P. A., Van Der Zee, S., Smallbone, K. L., Weijers, E. P., Monks, P. S., and Roekens, E.: Ultrafine particles in four European urban environments: Results from a new continuous long-term monitoring network, Atmos. Environ., 136, 68-81, https://doi.org/10.1016/j.atmosenv.2016.04.010, 2016.

Hussein, T., Junninen, H., Tunved, P., Kristensson, A., Dal Maso, M., Riipinen, I., Aalto, P. P., Hansson, H.-C., Swietlicki, E., and Kulmala, M.: Time span and spatial scale of regional new particle formation events over Finland and Southern Sweden, Atmos. Chem. Phys., 9, 4699-4716, https://doi.org/10.5194/acp-9-46992009, 2009.

Iida, K., Stolzenburg, M. R., McMurry, P. H., and Smith, J. N.: Estimating nanoparticle growth rates from sizedependent charged fractions: Analysis of new particle formation events in Mexico City, J. Geophys. Res.-Atmos., 113, 1-15, https://doi.org/10.1029/2007JD009260, 2008.

Jaatinen, A., Hamed, A., Joutsensaari, J., Mikkonen, S., Birmili, W. Wehner, B., Spindler, G., Wiedensohler, A., Decesari, S., Mircea, M., Facchini, M. C., Junninen, H., Kulmala, M., Lehtinen, K. E. J., and Laaksonen, A.: A comparison of new particle formation events in the boundary layer at three different sites in Europe, Boreal Environ. Res., 14, 481-498, 2009.

Järvi, L., Hannuniemi, H., Hussein, T., Junninen, H., Aalto, P., Hillamo, R., Mäkelä, T., Keronen, P., and Siivola, E.: The urban measurement station SMEAR III: Continuous monitoring of air pollution and surface - atmosphere interactions in Helsinki , Finland, Boreal Environ. Res., 14, 86-109, 2009.

Jeong, C.-H., Evans, G. J., McGuire, M. L., Chang, R. Y.-W., Abbatt, J. P. D., Zeromskiene, K., Mozurkewich, M., Li, S.M., and Leaitch, W. R.: Particle formation and growth at five rural and urban sites, Atmos. Chem. Phys., 10, 7979-7995, https://doi.org/10.5194/acp-10-7979-2010, 2010.

Kalivitis, N., Stavroulas, I., Bougiatioti, A., Kouvarakis, G., Gagné, S., Manninen, H. E., Kulmala, M., and Mihalopoulos, N.: Night-time enhanced atmospheric ion concentrations in the marine boundary layer, Atmos. Chem. Phys., 12, 3627-3638, https://doi.org/10.5194/acp-12-3627-2012, 2012.

Kalivitis, N., Kerminen, V.-M., Kouvarakis, G., Stavroulas, I., Bougiatioti, A., Nenes, A., Manninen, H. E., Petäjä, T., Kulmala, M., and Mihalopoulos, N.: Atmospheric new particle formation as a source of $\mathrm{CCN}$ in the eastern Mediterranean marine boundary layer, Atmos. Chem. Phys., 15, 9203-9215, https://doi.org/10.5194/acp-15-9203-2015, 2015.

Kalivitis, N., Kerminen, V.-M., Kouvarakis, G., Stavroulas, I., Tzitzikalaki, E., Kalkavouras, P., Daskalakis, N., Myriokefalitakis, S., Bougiatioti, A., Manninen, H. E., Roldin, P., Petäjä, T., Boy, M., Kulmala, M., Kanakidou, M., and Mihalopoulos, N.: Formation and growth of atmospheric nanoparticles in the eastern Mediterranean: results from long-term measurements and process simulations, Atmos. Chem. Phys., 19, 2671-2686, https://doi.org/10.5194/acp-19-2671-2019, 2019. 
Kalkavouras, P., Bossioli, E., Bezantakos, S., Bougiatioti, A., Kalivitis, N., Stavroulas, I., Kouvarakis, G., Protonotariou, A. P., Dandou, A., Biskos, G., Mihalopoulos, N., Nenes, A., and Tombrou, M.: New particle formation in the southern Aegean Sea during the Etesians: importance for $\mathrm{CCN}$ production and cloud droplet number, Atmos. Chem. Phys., 17, 175-192, https://doi.org/10.5194/acp-17-175-2017, 2017.

Kerminen, V. M., Pirjola, L., and Kulmala, M.: How significantly does coagulational scavenging limit atmospheric particle production?, J. Geophys. Res.-Atmos., 106, 24119-24125, https://doi.org/10.1029/2001JD000322, 2001.

Kerminen, V. M., Lehtinen, K. E. J., Anttila, T., and Kulmala, M.: Dynamics of atmospheric nucleation mode particles: A timescale analysis, Tellus B, 56, 135-146, https://doi.org/10.3402/tellusb.v56i2.16411, 2004.

Kerminen, V.-M., Chen, X., Vakkari, V., Petäjä, T., Kulmala, M., and Bianchi, F.: Atmospheric new particle formation and growth: review of field observations, Environ. Res. Lett., 13, 103003, https://doi.org/10.1088/1748-9326/aadf3c, 2018.

Ketzel, M., Wåhlin, P., Kristensson, A., Swietlicki, E., Berkowicz, R., Nielsen, O. J., and Palmgren, F.: Particle size distribution and particle mass measurements at urban,near-city and rural level in the Copenhagen area and Southern Sweden, Atmos. Chem. Phys., 4, 281-292, https://doi.org/10.5194/acp-4281-2004, 2004.

Korhonen, P., Kulmala, M., Laaksonen, A., Viisanen, Y., Mcgraw, R., and Seinfeld, J. H.: Ternary nucleation of $\mathrm{H}_{2} \mathrm{SO}_{4}, \mathrm{NH}_{3}$ and $\mathrm{H}_{2} \mathrm{O}$ in the atmosphere, J. Geophys. Res., 104, 26349-26353, https://doi.org/10.1029/1999JD900784, 1999.

Kouvarakis, G., Bardouki, H., and Mihalopoulos, N.: Sulfur budget above the Eastern Mediterranean: Relative contribution of anthropogenic and biogenic sources, Tellus B, 54, 201-212, https://doi.org/10.3402/tellusb.v54i3.16661, 2002.

Kristensson, A., Dal Maso, M., Swietlicki, E., Hussein, T., Zhou, J., Kerminen, V. M., and Kulmala, M.: Characterization of new particle formation events at a background site in southern Sweden: Relation to air mass history, Tellus B, 60, 330-344, 2008.

Kulmala, M., Dal Maso, M., Mäkelä, J. M., Pirjola, L., Väkevä, M., Aalto, P., Miikkulainen, P., Hämeri, K., and O'Dowd, C. D.: On the formation, growth and composition of nucleation mode particles, Tellus B, 53, 479-490, https://doi.org/10.3402/tellusb.v53i4.16622, 2001.

Kulmala, M., Vehkamäki, H., Petäjä, T., Dal Maso, M., Lauri, A., Kerminen, V. M., Birmili, W., and McMurry, P. H.: Formation and growth rates of ultrafine atmospheric particles: A review of observations, J. Aerosol Sci., 35, 143-176, https://doi.org/10.1016/j.jaerosci.2003.10.003, 2004a.

Kulmala, M., Laakso, L., Lehtinen, K. E. J., Riipinen, I., Dal Maso, M., Anttila, T., Kerminen, V.-M., Hõrrak, U., Vana, M., and Tammet, H.: Initial steps of aerosol growth, Atmos. Chem. Phys., 4, 2553-2560, https://doi.org/10.5194/acp-4-2553-2004, 2004b.

Kulmala, M., Petäjä, T., Mönkkönen, P., Koponen, I. K., Dal Maso, M., Aalto, P. P., Lehtinen, K. E. J., and Kerminen, V.-M.: On the growth of nucleation mode particles: source rates of condensable vapor in polluted and clean environments, Atmos. Chem. Phys., 5, 409-416, https://doi.org/10.5194/acp-5-409-2005, 2005.

Kulmala, M., Petäjä, T., Nieminen, T., Sipilä, M., Manninen, H. E., Lehtipalo, K., Dal Maso, M., Aalto, P. P., Junninen, H., Paasonen, P., Riipinen, I., Lehtinen, K. E. J., Laakso- nen, A., and Kerminen, V. M.: Measurement of the nucleation of atmospheric aerosol particles, Nat. Protoc., 7, 1651-1667, https://doi.org/10.1038/nprot.2012.091, 2012.

Kulmala, M., Kontkanen, J., Junninen, H., Lehtipalo, K., Manninen, H. E., Nieminen, T., Petaja, T., Sipila, M., Schobesberger, S., Rantala, P., Franchin, A., Jokinen, T., Jarvinen, E., Aijala, M., Kangasluoma, J., Hakala, J., Aalto, P. P., Paasonen, P., Mikkila, J., Vanhanen, J., Aalto, J., Hakola, H., Makkonen, U., Ruuskanen, T., Mauldin, R. L., Duplissy, J., Vehkamaki, H., Back, J., Kortelainen, A., Riipinen, I., Kurten, T., Johnston, M. V., Smith, J. N., Ehn, M., Mentel, T. F., Lehtinen, K. E. J. J., Laaksonen, A., Kerminen, V.-M. V. M., Worsnop, D. R., Petäjä, T., Sipilä, M., Schobesberger, S., Rantala, P., Franchin, A., Jokinen, T., Järvinen, E., Äijälä, M., Kangasluoma, J., Hakala, J., Aalto, P. P., Paasonen, P., Mikkilä, J., Vanhanen, J., Aalto, J., Hakola, H., Makkonen, U., Ruuskanen, T., Mauldin, R. L., Duplissy, J., Vehkamäki, H., Bäck, J., Kortelainen, A., Riipinen, I., Kurtén, T., Johnston, M. V., Smith, J. N., Ehn, M., Mentel, T. F., Lehtinen, K. E. J. J., Laaksonen, A., Kerminen, V.-M., and Worsnop, D. R.: Direct observations of atmospheric aerosol nucleation, Science, 339, 943946, https://doi.org/10.1126/science.1227385, 2013.

Kulmala, M., Kontkanen, J., Junninen, H., Lehtipalo, K., Manninen, H. E., Nieminen, T., Petäjä, T., Sipilä, M., Schobesberger, S., Rantala, P., Franchin, A., Jokinen, T., Järvinen, E., Äijälä, M., Kangasluoma, J., Hakala, J., Aalto, P. P., Paasonen, P., Mikkilä, J., Vanhanen, J., Aalto, J., Hakola, H., Makkonen, U., Ruuskanen, T., Mauldin, R. L., Duplissy, J., Vehkamäki, H., Bäck, J., Kulmala, M., Petäjä, T., Ehn, M., Thornton, J., Sipilä, M., Worsnop, D. R., and Kerminen, V.-M.: Chemistry of atmospheric nucleation: On the recent advances on precursor characterization and atmospheric cluster composition in connection with atmospheric new particle formation, Annu. Rev. Phys. Chem., 65, 21-37, https://doi.org/10.1146/annurev-physchem040412-110014, 2014.

Kumar, P., Morawska, L., Birmili, W., Paasonen, P., Hu, M., Kulmala, M., Harrison, R. M., Norford, L., and Britter, R.: Ultrafine particles in cities, Environ. Int., 66, 1-10, https://doi.org/10.1016/j.envint.2014.01.013, 2014.

Kupiainen, K., Ritola, R., Stojiljkovic, A., Pirjola, L., Malinen, A., and Niemi, J.: Contribution of mineral dust sources to street side ambient and suspension $\mathrm{PM}_{10}$ samples, Atmos. Environ., 147, 178-189, https://doi.org/10.1016/j.atmosenv.2016.09.059, 2016.

Li, X., Chee, S., Hao, J., Abbatt, J. P. D., Jiang, J., and Smith, J. N.: Relative humidity effect on the formation of highly oxidized molecules and new particles during monoterpene oxidation, Atmos. Chem. Phys., 19, 1555-1570, https://doi.org/10.5194/acp19-1555-2019, 2019.

Ma, N. and Birmili, W.: Estimating the contribution of photochemical particle formation to ultrafine particle number averages in an urban atmosphere, Sci. Total Environ., 512-513, 154-166, https://doi.org/10.1016/j.scitotenv.2015.01.009, 2015.

Makkonen, R., Asmi, A., Kerminen, V.-M., Boy, M., Arneth, A., Hari, P., and Kulmala, M.: Air pollution control and decreasing new particle formation lead to strong climate warming, Atmos. Chem. Phys., 12, 1515-1524, https://doi.org/10.5194/acp12-1515-2012, 2012.

Masiol, M., Harrison, R. M., Vu, T. V., and Beddows, D. C. S.: Sources of sub-micrometre particles near a major in- 
ternational airport, Atmos. Chem. Phys., 17, 12379-12403, https://doi.org/10.5194/acp-17-12379-2017, 2017.

McFiggans, G., Mentel, T. F., Wildt, J., Pullinen, I., Kang, S., Kleist, E., Schmitt, S., Springer, M., Tillmann, R., Wu, C., Zhao, D., Hallquist, M., Faxon, C., Le Breton, M., Hallquist, Å. M., Simpson, D., Bergström, R., Jenkin, M. E., Ehn, M., Thornton, J. A., Alfarra, M. R., Bannan, T. J., Percival, C. J., Priestley, M., Topping, D., and Kiendler-Scharr, A.: Secondary organic aerosol reduced by mixture of atmospheric vapours, Nature, 565, 587-593, https://doi.org/10.1038/s41586-018-0871-y, 2019.

Minguillón, M. C., Brines, M., Pérez, N., Reche, C., Pandolfi, M., Fonseca, A. S., Amato, F., Alastuey, A., Lyasota, A., Codina, B., Lee, H. K., Eun, H. R., Ahn, K. H., and Querol, X.: New particle formation at ground level and in the vertical column over the Barcelona area, Atmos. Res., 164-165, 118-130, https://doi.org/10.1016/j.atmosres.2015.05.003, 2015.

Napari, I., Noppel, M., Vehkamäki, H., and Kulmala, M.: An improved model for ternary nucleation of sulfuric acid-ammonia-water, J. Chem. Phys., 116, 4221-4227, https://doi.org/10.1063/1.1450557, 2002.

Németh, Z. and Salma, I.: Spatial extension of nucleating air masses in the Carpathian Basin, Atmos. Chem. Phys., 14, 8841-8848, https://doi.org/10.5194/acp-14-8841-2014, 2014.

Nieminen, T., Asmi, A., Maso, M. D., Aalto, P. P., Keronen, P., Petäjä, T., Kulmala, M., and Kerminen, V.: Trends in atmospheric new-particle formation: 16 years of observations in a borealforest environment, Boreal Environ. Res., 19, 191-214, 2014.

Nilsson, E. D., Rannik, Ü., Kulmala, M., Buzorius, G., and O'Dowd, C. D.: Effects of continental boundary layer evolution, convection, turbulence and entrainment, on aerosol formation, Tellus B, 53, 441-461, https://doi.org/10.3402/tellusb.v53i4.16617, 2001.

Olin, M., Kuuluvainen, H., Aurela, M., Kalliokoski, J., Kuittinen, N., Isotalo, M., Timonen, H. J., Niemi, J. V., Rönkkö, T., and Dal Maso, M.: Traffic-originated nanocluster emission exceeds $\mathrm{H}_{2} \mathrm{SO}_{4}$-driven photochemical new particle formation in an urban area, Atmos. Chem. Phys., 20, 1-13, https://doi.org/10.5194/acp20-1-2020, 2020.

Ortega, I. K., Kurtén, T., Vehkamäki, H., and Kulmala, M.: The role of ammonia in sulfuric acid ion induced nucleation, Atmos. Chem. Phys., 8, 2859-2867, https://doi.org/10.5194/acp-8-28592008, 2008.

Park, M., Yum, S. S., and Kim, J. H.: Characteristics of submicron aerosol number size distribution and new particle formation events measured in Seoul, Korea, during 2004-2012, AsiaPacific J. Atmos. Sci., 51, 1-10, https://doi.org/10.1007/s13143014-0055-0, 2015.

Peng, Y., Dong, Y., Li, X., Liu, X., Dai, J., Chen, C., Dong, Z., Du, C., and Wang, Z.: Different characteristics of new particle formation events at two suburban sites in northern China, Atmosphere, 8, 258, https://doi.org/10.3390/atmos8120258, 2017.

Petäjä, T., Mauldin, III, R. L., Kosciuch, E., McGrath, J., Nieminen, T., Paasonen, P., Boy, M., Adamov, A., Kotiaho, T., and Kulmala, M.: Sulfuric acid and $\mathrm{OH}$ concentrations in a boreal forest site, Atmos. Chem. Phys., 9, 7435-7448, https://doi.org/10.5194/acp9-7435-2009, 2009.

Poling, B. E., Prausnitz, J. M., and O’Connell, J. P.: The properties of gases and liquids, 5th Edn., McGraw-Hill Education, New York, USA, 768 pp., 2001.
Politis, M., Pilinis, C., and Lekkas, T. D.: Ultrafine particles (UFP) and health effects. Dangerous. Like no other PM? Review and analysis, Glob. Nest J., 10, 439-452, 2008.

Querol, X., Gangoiti, G., Mantilla, E., Alastuey, A., Minguillón, M. C., Amato, F., Reche, C., Viana, M., Moreno, T., Karanasiou, A., Rivas, I., Pérez, N., Ripoll, A., Brines, M., Ealo, M., Pandolfi, M., Lee, H.-K., Eun, H.-R., Park, Y.-H., Escudero, M., Beddows, D., Harrison, R. M., Bertrand, A., Marchand, N., Lyasota, A., Codina, B., Olid, M., Udina, M., Jiménez-Esteve, B., Soler, M. R., Alonso, L., Millán, M., and Ahn, K.-H.: Phenomenology of high-ozone episodes in NE Spain, Atmos. Chem. Phys., 17, 2817-2838, https://doi.org/10.5194/acp-17-2817-2017, 2017.

Riccobono, F., Schobesberger, S., Scott, C. E., Dommen, J., Ortega, I. K., Rondo, L., Almeida, J., Amorim, A., Bianchi, F., Breitenlechner, M., David, A., Downard, A., Dunne, E. M., Duplissy, J., Ehrhart, S., Flagan, R. C., Franchin, A., Hansel, A., Junninen, H., Kajos, M., Keskinen, H., Kupc, A., Makhmutov, V., Mathot, S., Nieminen, T., Onnela, A., Petäjä, T., Tsagkogeorgas, G., Vaattovaara, P., Viisanen, Y., Vrtala, A., and Wagner, P. E.: Oxidation Products of Biogenic Atmospheric Particles, Science, 717, 717722, https://doi.org/10.1126/science.1243527, 2014.

Riipinen, I., Sihto, S.-L., Kulmala, M., Arnold, F., Dal Maso, M., Birmili, W., Saarnio, K., Teinilä, K., Kerminen, V.-M., Laaksonen, A., and Lehtinen, K. E. J.: Connections between atmospheric sulphuric acid and new particle formation during QUEST III-IV campaigns in Heidelberg and Hyytiälä, Atmos. Chem. Phys., 7, 1899-1914, https://doi.org/10.5194/acp-7-1899-2007, 2007.

Rimnácová, D., Ždímal, V., Schwarz, J., Smolík, J., and Rimnác, M.: Atmospheric aerosols in suburb of Prague: The dynamics of particle size distributions, Atmos. Res., 101, 539-552, https://doi.org/10.1016/j.atmosres.2010.10.024, 2011.

Rivas, I., Beddows, D. C. S., Amato, F., Green, D. C., Järvi, L., Hueglin, C., Reche, C., Timonen, H., Fuller, G. W., Niemi, J. V, Pérez, N., Aurela, M., Hopke, P. K., Alastuey, A., Kulmala, M., Harrison, R. M., Querol, X., and Kelly, F. J.: Source apportionment of particle number size distribution in urban background and traffic stations in four European cities, Environ. Int., 135, 105345, https://doi.org/10.1016/j.envint.2019.105345, 2020.

Rodríguez, S., Querol, X., Alastuey, A., Kallos, G., and Kakaliagou, O.: Saharan dust contributions to $\mathrm{PM}_{10}$ and TSP levels in Southern and Eastern Spain, Atmos. Environ., 35, 2433-2447, https://doi.org/10.1016/S1352-2310(00)00496-9, 2001.

Rönkkö, T., Kuuluvainen, H., Karjalainen, P., Keskinen, J., Hillamo, R., Niemi, J. V., Pirjola, L., Timonen, H. J., Saarikoski, S., Saukko, E., Järvinen, A., Silvennoinen, H., Rostedt, A., Olin, M., Yli-Ojanperä, J., Nousiainen, P., Kousa, A., and Dal Maso, M.: Traffic is a major source of atmospheric nanocluster aerosol, P. Natl. Acad. Sci., 114, 7549-7554, https://doi.org/10.1073/pnas.1700830114, 2017.

Salma, I., Borsós, T., Németh, Z., Weidinger, T., Aalto, P., and Kulmala, M.: Comparative study of ultrafine atmospheric aerosol within a city, Atmos. Environ., 92, 154-161, https://doi.org/10.1016/j.atmosenv.2014.04.020, 2014.

Salma, I., Németh, Z., Kerminen, V.-M., Aalto, P., Nieminen, T., Weidinger, T., Molnár, Á., Imre, K., and Kulmala, M.: Regional effect on urban atmospheric nucleation, Atmos. Chem. Phys., 16, 8715-8728, https://doi.org/10.5194/acp-16-8715-2016, 2016. 
Sarnela, N., Jokinen, T., Nieminen, T., Lehtipalo, K., Junninen, H., Kangasluoma, J., Hakala, J., Taipale, R., Larnimaa, K., Westerholm, H., Schobesberger, S., Sipil, M., Heijari, J., Kerminen, V., and Pet, T.: Sulphuric acid and aerosol particle production in the vicinity of an oil refinery, Atmos. Environ., 119, 156-166, https://doi.org/10.1016/j.atmosenv.2015.08.033, 2015.

Schobesberger, S., Franchin, A., Bianchi, F., Rondo, L., Duplissy, J., Kürten, A., Ortega, I. K., Metzger, A., Schnitzhofer, R., Almeida, J., Amorim, A., Dommen, J., Dunne, E. M., Ehn, M., Gagné, S., Ickes, L., Junninen, H., Hansel, A., Kerminen, V.-M., Kirkby, J., Kupc, A., Laaksonen, A., Lehtipalo, K., Mathot, S., Onnela, A., Petäjä, T., Riccobono, F., Santos, F. D., Sipilä, M., Tomé, A., Tsagkogeorgas, G., Viisanen, Y., Wagner, P. E., Wimmer, D., Curtius, J., Donahue, N. M., Baltensperger, U., Kulmala, M., and Worsnop, D. R.: On the composition of ammonia-sulfuric-acid ion clusters during aerosol particle formation, Atmos. Chem. Phys., 15, 55-78, https://doi.org/10.5194/acp-15-55-2015, 2015.

Seinfeld, J. H. and Pandis, S. N.: Atmospheric Chemistry and Physics: From Air Pollution to Climate Change, 3rd Edn., John Wiley \& Sons, Inc, New Jersey, Canada, 2012.

Shen, X., Sun, J., Kivekäs, N., Kristensson, A., Zhang, X., Zhang, Y., Zhang, L., Fan, R., Qi, X., Ma, Q., and Zhou, H.: Spatial distribution and occurrence probability of regional new particle formation events in eastern China, Atmos. Chem. Phys., 18, 587599, https://doi.org/10.5194/acp-18-587-2018, 2018.

Shi, J. P., Evans, D. E., Khan, A. A., and Harrison, R. M.: Sources and concentration of nanoparticles $(10 \mathrm{~nm}$ diameter) in the urban atmosphere, Atmos. Environ., 35, 1193-1202, doi.org/10.1016/S1352-2310(00)00418-0, 2001.

Siakavaras, D., Samara, C., Petrakakis, M., and Biskos, G.: Nucleation events at a coastal city during the warm period: Kerbside versus urban background measurements, Atmos. Environ., 140, 60-68, https://doi.org/10.1016/j.atmosenv.2016.05.054, 2016.

Sipila, M., Berndt, T., Petaja, T., Brus, D., Vanhanen, J., Stratmann, F., Patokoski, J., Mauldin III, R. L., Hyvarinen, A. P., Lihavainen, H., and Kulmala, M.: The role of sulfuric acid in atmospheric nucleation, Science, 327, 1243-1246, https://doi.org/10.1126/science.1180315, 2010.

Spracklen, D. V., Carslaw, K. S., Kulmala, M., Kerminen, V. M., Sihto, S. L., Riipinen, I., Merikanto, J., Mann, G. W., Chipperfield, M. P., Wiedensohler, A., Birmili, W., and Lihavainen, H.: Contribution of particle formation to global cloud condensation nuclei concentrations, Geophys. Res. Lett., 35, 1-5, https://doi.org/10.1029/2007GL033038, 2008.

Stafoggia, M., Schneider, A., Cyrys, J., Samoli, E., Andersen, Z. J., Bedada, G. B., Bellander, T., Cattani, G., Eleftheriadis, K., Faustini, A., Hoffmann, B., Jacquemin, B., Katsouyanni, K., Massling, A., Pekkanen, J., Perez, N., Peters, A., Quass, U., Yli-Tuomi, T., and Forastiere, F.: Association between short-term exposure to ultrafine particles and mortality in eight European Urban areas, Epidemiology, 28, 172-180, https://doi.org/10.1097/EDE.0000000000000599, 2017.

Stanier, C. O., Khlystov, A. Y., and Pandis, S. N.: Nucleation events during the Pittsburgh Air Quality Study: Description and relation to key meteorological, gas phase, and aerosol parameters, Aerosol Sci. Tech., 38, 253-264, https://doi.org/10.1080/02786820390229570, 2004.

Stojiljkovic, A., Kauhaniemi, M., Kukkonen, J., Kupiainen, K., Karppinen, A., Denby, B. R., Kousa, A., Niemi, J. V., and Ket- zel, M.: The impact of measures to reduce ambient air $\mathrm{PM}_{10}$ concentrations originating from road dust, evaluated for a street canyon in Helsinki, Atmos. Chem. Phys., 19, 11199-11212, https://doi.org/10.5194/acp-19-11199-2019, 2019.

Sun, J., Birmili, W., Hermann, M., Tuch, T., Weinhold, K., Spindler, G.,Schladitz, A., Bastian, S., Löschau, G., Cyrys, J., Gu, J., Flentje, H., Briel, B., Asbach, C., Kaminski, H.,Ries, L., Sohmer, R., Gerwig, H., Wirtz, K., Meinhardt, F., Schwerin, A., Bath, O., Ma, N., and Wiedensohler, A.: Variability of Black Carbon mass concentrations, sub-micrometer particle number concentrations and size distributions: Results of the German Ultrafine Aerosol Network ranging from city street to high Alpine locations, Atmos. Environ., 202, 256-268, 2019.

Tobías, A., Rivas, I., Reche, C., Alastuey, A., Rodríguez, S., Fernández-camacho, R., Sánchez, A. M., Campa, D., De, J., Sunyer, J., and Querol, X.: Short-term e ff ects of ultra fi ne particles on daily mortality by primary vehicle exhaust versus secondary origin in three Spanish cities, Environ. Int., 111, 144-151, https://doi.org/10.1016/j.envint.2017.11.015, 2018.

Tröstl, J., Chuang, W. K., Gordon, H., Heinritzi, M., Yan, C., Molteni, U., Ahlm, L., Frege, C., Bianchi, F., Wagner, R., Simon, M., Lehtipalo, K., Williamson, C., Craven, J. S., Duplissy, J., Adamov, A., Almeida, J., Bernhammer, A. K., Breitenlechner, M., Brilke, S., Dias, A., Ehrhart, S., Flagan, R. C., Franchin, A., Fuchs, C., Guida, R., Gysel, M., Hansel, A., Hoyle, C. R., Jokinen, T., Junninen, H., Kangasluoma, J., Keskinen, H., Kim, J., Krapf, M., Kürten, A., Laaksonen, A., Lawler, M., Leiminger, M., Mathot, S., Möhler, O., Nieminen, T., Onnela, A., Petäjä, T., Piel, F. M., Miettinen, P., Rissanen, M. P., Rondo, L., Sarnela, N., Schobesberger, S., Sengupta, K., Sipilä, M., Smith, J. N., Steiner, G., Tomè, A., Virtanen, A., Wagner, A. C., Weingartner, E., Wimmer, D., Winkler, P. M., Ye, P., Carslaw, K. S., Curtius, J., Dommen, J., Kirkby, J., Kulmala, M., Riipinen, I., Worsnop, D. R., Donahue, N. M., and Baltensperger, U.: The role of low-volatility organic compounds in initial particle growth in the atmosphere, Nature, 533, 527-531, https://doi.org/10.1038/nature18271, 2016.

Voigtländer, J., Tuch, T., Birmili, W., and Wiedensohler, A.: Correlation between traffic density and particle size distribution in a street canyon and the dependence on wind direction, Atmos. Chem. Phys., 6, 4275-4286, https://doi.org/10.5194/acp-6-42752006, 2006.

Vratolis, S., Gini, M. I., Bezantakos, S., Stavroulas, I., Kalivitis, N., Kostenidou, E., Louvaris, E., Siakavaras, D., Biskos, G., Mihalopoulos, N., Pandis, S. N. N., Pilinis, C., Papayannis, A., and Eleftheriadis, K.: Particle number size distribution statistics at City-Centre Urban Background, urban background, and remote stations in Greece during summer, Atmos. Environ., 213, 711726, https://doi.org/10.1016/j.atmosenv.2019.05.064, 2019.

Vrekoussis, M., Richter, A., Hilboll, A., Burrows, J. P., Gerasopoulos, E., Lelieveld, J., Barrie, L., Zerefos, C., and Mihalopoulos, N.: Economic crisis detected from space: Air quality observations over Athens/Greece, Geophys. Res. Lett., 40, 458-463, https://doi.org/10.1002/grl.50118, 2013.

Wang, D., Guo, H., Cheung, K., and Gan, F.: Observation of nucleation mode particle burst and new particle formation events at an urban site in Hong Kong, Atmos. Environ., 99, 196-205, https://doi.org/10.1016/j.atmosenv.2014.09.074, 2014. 
Wang, F., Ketzel, M., Ellermann, T., Wåhlin, P., Jensen, S. S., Fang, D., and Massling, A.: Particle number, particle mass and $\mathrm{NO}_{x}$ emission factors at a highway and an urban street in Copenhagen, Atmos. Chem. Phys., 10, 2745-2764, https://doi.org/10.5194/acp-10-2745-2010, 2010.

Wang, F., Zhang, Z., Massling, A., Ketzel, M., and Kristensson, A.: Particle formation events measured at a semirural background site in Denmark, Environ. Sci. Pollut. Res., 20, 3050-3059, https://doi.org/10.1007/s11356-012-1184-6, 2013.

Wang, Z., Wu, Z., Yue, D., Shang, D., Guo, S., Sun, J., Ding, A., Wang, L., Jiang, J., Guo, H., Gao, J., Cheung, H. C., Morawska, L., Keywood, M., and Hu, M.: New particle formation in China: Current knowledge and further directions, Sci. Total Environ., 577, 258-266, https://doi.org/10.1016/j.scitotenv.2016.10.177, 2017.

Weber, R. J., McMurry, P. H., Eisele, F. L., and Tanner, D. J.: Measurement of expected nucleation precursor species and 3-500-nm diameter particles at Mauna Loa Observatory, Hawaii, J. Atmos. Sci., 52, 2242-2257, 1995.

Weber, R. J., McMurry, P. H., Mauldin, L., Tanner, D. J., Eisele, F. L., Brechtel, F. J., Kreidenweis, S. M., Kok, G. L., Schillawski, R. D., Baumgardner, D., and Baumgardner, B.: A study of new particle formation and growth involving biogenic and trace gas species measured during ACE 1, J. Geophys. Res.-Atmos., 103, 16385-16396, https://doi.org/10.1029/97JD02465, 1998.

Wehner, B., Siebert, H., Stratmann, F., Tuch, T., Wiedensohler, A., Petäjä, T., Dal Maso, M., and Kulmala, M.: Horizontal homogeneity and vertical extent of new particle formation events, Tellus B, 59, 362-371, https://doi.org/10.1111/j.16000889.2007.00260.x, 2007.

Wonaschütz, A., Demattio, A., Wagner, R., Burkart, J., Zíková, N., Vodička, P., Ludwig, W., Steiner, G., Schwarz, J., and Hitzenberger, R.: Seasonality of new particle formation in Vienna, Austria - Influence of air mass origin and aerosol chemical composition, Atmos. Environ., 118, 118-126, https://doi.org/10.1016/j.atmosenv.2015.07.035, 2015.
Woo, K. S., Chen, D. R., Pui, D. Y. H. H., and McMurry, P. H.: Measurement of Atlanta aerosol size distributions: Observations of lutrafine particle events, Aerosol Sci. Tech., 34, 75-87, https://doi.org/10.1080/02786820120056, 2001.

Xiao, S., Wang, M. Y., Yao, L., Kulmala, M., Zhou, B., Yang, X., Chen, J. M., Wang, D. F., Fu, Q. Y., Worsnop, D. R., and Wang, L.: Strong atmospheric new particle formation in winter in urban Shanghai, China, Atmos. Chem. Phys., 15, 1769-1781, https://doi.org/10.5194/acp-15-1769-2015, 2015.

Yao, L., Garmash, O., Bianchi, F., Zheng, J., Yan, C., Kontkanen, J., Junninen, H., Mazon, S. B., Ehn, M., Paasonen, P., Sipilä, M., Wang, M., Wang, X., Xiao, S., Chen, H., Lu, Y., Zhang, B., Wang, D., Fu, Q., Geng, F., Li, L., Wang, H., Qiao, L., Yang, X., Chen, J., Kerminen, V. M., Petäjä, T., Worsnop, D. R., Kulmala, M., and Wang, L.: Atmospheric new particle formation from sulfuric acid and amines in a Chinese megacity, Science, 361, 278281, https://doi.org/10.1126/science.aao4839, 2018.

Yli-Juuti, T., Nieminen, T., Hirsikko, A., Aalto, P. P., Asmi, E., Hõrrak, U., Manninen, H. E., Patokoski, J., Dal Maso, M., Petäjä, T., Rinne, J., Kulmala, M., and Riipinen, I.: Growth rates of nucleation mode particles in Hyytiälä during 20032009: variation with particle size, season, data analysis method and ambient conditions, Atmos. Chem. Phys., 11, 12865-12886, https://doi.org/10.5194/acp-11-12865-2011, 2011.

ҮПЕКА (Ministry for the Environment, Energy and Climate Change in Greece): Annual report of atmospheric pollution 2011, Ministry for the Environment, Energy and Climate Change in Greece, Department of Air Quality, April 2012, available at: http://www.ypeka.gr/LinkClick.aspx?fileticket= TYgrT0qoSrI\%3D\&tabid=490\&language $=$ el - GR (last access: 18 September 2019), 2012.

Ždímal, V., Smolík, J., Eleftheriadis, K., Wagner, Z., Housiadas, C., Mihalopoulos, N., Mikuška, P., Večeřa, Z., Kopanakis, I., and Lazaridis, M.: Dynamics of atmospheric aerosol number size distributions in the eastern Mediterranean during the "SUB-AERO" project, Water. Air. Soil Poll., 214, 133-146, https://doi.org/10.1007/s11270-010-0410-4, 2011. 